\title{
Deep sequencing-based transcriptome analysis of Plutella xylostella larvae parasitized by Diadegma semiclausum
}

Kayvan Etebari ${ }^{1}$, Robin W Palfreyman ${ }^{2}$, David Schlipalius ${ }^{3}$, Lars K Nielsen², Richard V Glatz ${ }^{4}$ and Sassan Asgari ${ }^{*}$

\begin{abstract}
Background: Parasitoid insects manipulate their hosts' physiology by injecting various factors into their host upon parasitization. Transcriptomic approaches provide a powerful approach to study insect host-parasitoid interactions at the molecular level. In order to investigate the effects of parasitization by an ichneumonid wasp (Diadegma semiclausum) on the host (Plutella xylostella), the larval transcriptome profile was analyzed using a short-read deep sequencing method (Illumina). Symbiotic polydnaviruses (PDVs) associated with ichneumonid parasitoids, known as ichnoviruses, play significant roles in host immune suppression and developmental regulation. In the current study, D. semiclausum ichnovirus (DsIV) genes expressed in P. xylostella were identified and their sequences compared with other reported PDVs. Five of these genes encode proteins of unknown identity, that have not previously been reported.
\end{abstract}

Results: De novo assembly of cDNA sequence data generated 172,660 contigs between 100 and 10000 bp in length; with $35 \%$ of $>200$ bp in length. Parasitization had significant impacts on expression levels of 928 identified insect host transcripts. Gene ontology data illustrated that the majority of the differentially expressed genes are involved in binding, catalytic activity, and metabolic and cellular processes. In addition, the results show that transcription levels of antimicrobial peptides, such as gloverin, cecropin E and lysozyme, were up-regulated after parasitism. Expression of ichnovirus genes were detected in parasitized larvae with 19 unique sequences identified from five PDV gene families including vankyrin, viral innexin, repeat elements, a cysteine-rich motif, and polar residue rich protein. Vankyrin 1 and repeat element 1 genes showed the highest transcription levels among the DsIV genes.

Conclusion: This study provides detailed information on differential expression of $P$. xylostella larval genes following parasitization, DSIV genes expressed in the host and also improves our current understanding of this host-parasitoid interaction.

\section{Background}

Endoparasitoids of the insect order Hymenoptera inject their eggs inside a host insect where they hatch and subsequently feed on the host until its death. For successful parasitism, endoparasitoids bring about a change in their hosts' conditions in favour of the developing parasitoid larvae. For this purpose, female wasps introduce secretions such as venom or ovary fluids, which may contain symbiotic viruses (polydnavirus (PDV) and/

\footnotetext{
* Correspondence: s.asgari@uq.edu.au

'School of Biological Sciences, The University of Queensland, St Lucia QLD 4072 Australia

Full list of author information is available at the end of the article
}

or virus-like particles), and other maternal factors, into the host [1]. In addition to suppression of the host immune system to protect the developing parasitoid, several studies have shown that parasitoids and their introduced maternal factors have significant effects on host metabolism and development such as plasma protein composition, food consumption, endocrine system activity and even on regulatory microRNA levels [2-8].

Diadegma semiclausum Hellén is an ichneumonid endoparasitoid that carries a PDV with a circular, double-stranded and segmented DNA genome encoding proteins that suppress the host immune response and cause developmental arrest/delay [9]. PDVs are the most

\section{Biomed Central}


highly characterized of the known mutualistic viruses [10], replicating only within the calyx cells of the reproductive tract of female wasps [11]. No virus replication occurs in parasitized larvae; however expression of encapsidated PDV genes induces different physiological modifications such as interruption of the larval endocrine system and suppression of the host immune system [12-15].

PDVs are classified into two genera based on their host wasp families; Ichnovirus containing ichnoviruses (IVs) and Bracovirus containing bracoviruses (BVs) $[11,16]$. These genera are morphologically distinct and their gene functions vary. Analysis of virion structural components from IVs indicates that the set of structural genes is conserved among wasps associated with IVs and might originate from an ancestral virus [17]. Recently, Bigot et al. suggested that IVs originated from ascoviruses by lateral transfer of ascoviral genes into wasp genomes [18]. Interestingly, the DNA that is encapsidated within PDVs appears more similar to that of eukaryotes than that of other viral genomes [19]. It has been demonstrated that less than $2 \%$ of encapsidated PDV genes have homologs in other viruses in contrast to the proviral or structural genes [20]. Most of the PDV DNA appear to be non-coding, except for some groups of genes that are involved in host immune suppression pathways [21]. IV genomes generally encompass more than 20 circular DNA segments ranging in size from 2-28 $\mathrm{Kb}$ with estimated total genome sizes ranging from $75 \mathrm{~Kb}$ to greater than $250 \mathrm{~Kb}$ [20].

Research so far has concentrated mainly on individual genes or small defined groups of host or PDV genes, to explore their function or differential expression following parasitization. Deep sequencing data can provide extensive information about host-parasitoid interactions at the transcriptome level. The large amount of sequencing data that can readily be produced by next-generation sequencing platforms, such as the Illumina GAII, reduces the need for prior sequence knowledge for gene expression profiling and are now making direct sequencing approaches the method of choice for whole transcriptome analysis in many species [22-26]. The large numbers of short reads produced by next-generation sequencers provide opportunities for development of new applications where sequencing only a portion of a molecule is sufficient. However, the analysis of transcriptome data produced by these technologies for organisms with limited genomic information still presents challenges because the sequenced fragments must be aligned against existing good quality reference genomes [27].

In this study, we used deep sequencing to explore the impact of $D$. semiclausum parasitization on its host, Diamondback moth Plutella xylostella L. (Lepidoptera,
Plutellidae), a notorious pest of cruciferous plants. $P$. xylostella has developed resistance to many groups of chemical insecticides and also Bacillus thuringiensis endotoxin $[28,29]$. This has made $P$. xylostella one of the world's most destructive insect pests and the estimated global cost of controlling this insect is around US $\$ 1$ billion annually [28]. This emphasizes the necessity for the continued development of innovative alternative control measures and resistance management strategies. Parasitoids or parasitoid-produced regulatory molecules can be used to improve conventional pest control strategies in sustainable agriculture. We have used a deep sequencing approach to give a comprehensive view of immune- and metabolic-related genes that are differentially expressed in parasitized versus non-parasitized $P$. xylostella larvae, revealing a significant number of $D$. semiclausum ichnovirus genes (DsIV) which have not been reported previously. This type of study may facilitate new controls for pest larvae by identifying molecules that are crucial for larval immune defence, development, pesticide resistance and other important metabolic regulatory functions.

\section{Results and Discussion}

\section{$P$. xylostella transcriptome profile}

A transcriptome is the complete set of expressed RNA transcripts in one or more cells. Transcriptome profiling of organisms under stress or parasitization challenge helps us to obtain a better understanding of subsequent related cellular activities in organisms including growth, development, and immune defence. Recently, the newly developed deep sequencing approaches have significantly changed how the functional complexity of the transcriptome can be investigated [22,25,30].

To analyse the transcriptome of $P$. xylostella host larvae following parasitization by $D$. semiclausum, RNA samples isolated from the whole host larvae at various time points after parasitization were pooled together prior to sequencing. This may lead to bias in the results (e.g. a gene may first be up-regulated and down-regulated subsequently); however, we aimed at obtaining an overview of what occurs during parasitism and generating a transcriptome of $P$. xylostella which has not been previously available and to isolate as many DsIV genes as possible. Illumina GAII RNAseq deep sequencing analysis produced approximately 26.6 and 27.1 million single-end reads from RNA extracted from the whole body of non-parasitized (control) and parasitized larvae of P. xylostella, respectively. De novo assembly using the CLC Genomic Workbench produced 172,660 contigs with a minimum contig size of $100 \mathrm{bp}$; of these, $66 \%$ were between 100-199 bp and only 59,255 (34\%) of the contigs were above 200 bp (Table 1). Only contigs above $200 \mathrm{bp}$ were selected for further analysis and $6 \%$ 
Table 1 Summary of contig statistics resulting from Illumina deep sequencing of parasitized and nonparasitized $P$. xylostella larvae

\begin{tabular}{lc}
\hline Parameters & Number \\
\hline Total de novo assembled contigs with CLC software & 172,660 \\
Contigs used for BLAST (cut-off: above 200 bp length) & 59,255 \\
Best BLAST matches (cut-off: E-value > E-6) & 26119 \\
No Hits (contigs without any BLAST match) & 33136 \\
Not mapped with any Gene Ontology (GO) database & 6087 \\
Annotated sequences (cut off: GO weight 5E value > E-6) & 20704 \\
\hline
\end{tabular}

of these had nucleotide lengths above 1000 bp (Figure 1). We found 4992 contigs that shared their greatest homology with Tribolium castaneum (Coleoptera) genes with a minimum E-value of 1e-06. Bombyx mori (silkworm) was another species with which a range of $P$. xylostella genes showed high levels of homology. One reason for the higher number of hits against the beetle genome is that three times more $T$. castaneum genes than B. mori genes are reported in databases.

The short-read data generated by deep sequencing may be problematic when annotating alternative splice variants [24]. However, many gene expression profiling studies that use high-throughput sequencing can also provide valuable annotation information, such as existence of novel genes, exons or splice events which can be used to annotate putative gene sequences for other species. For instance, 39\% of the reads from the brain transcriptome of the wasp, Polistes metricus, were matched to the honeybee (Apis mellifera) genome sequence and EST resources, for annotation [31]. Using a series of filtering and critical cut-off values for BLAST E-value and gene

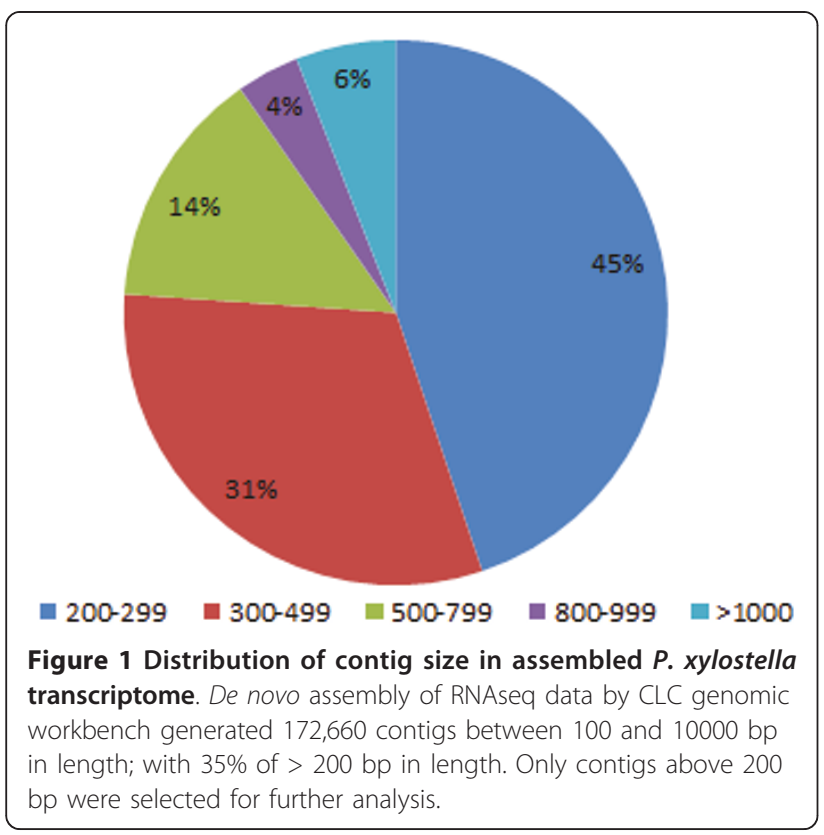

ontology (GO) weighting, 20,704 sequences were annotated by B2GO software http://www.blast2go.org through UniProt KB/TrEMBL and other available databases. GOannotated consensus sequences were assigned to biological process clusters such as cellular component and molecular function, and distributed among various subcategories such as metabolism, growth, development, apoptosis, immune defense, molecular processing, signal transduction, transcription regulator activity, catalytic activity etc. (Figure 2).

Comparison of the transcriptome pattern of P. xylostella for eight different GO terms (molecular function Level 2) with those of silkworm http://www.silkdb.org showed high similarity in the distribution of genes across $\mathrm{GO}$ categories indicating that the transcriptome analysed was not biased towards particular categories (Figure 3).

Overall, from the assembled contigs of over $200 \mathrm{bp}$ in length, $44 \%$ showed similarity with genes or proteins in the NCBI database. The rest may represent unknown genes, non-coding RNA or misassembled contigs that are expected due to the presence of large repetitive or duplicated regions. David et al. (2010) suggested that a significant proportion of transcript signatures detected outside predicted genes represent regulatory non-coding RNAs, because these large numbers of non-coding RNA can be antisense, intergenic or overlapping with protein-coding genes [22].

\section{Effects of parasitism on the transcription of host immune- related genes}

Our sequencing data analyses indicate that parasitism has a significant impact on the transcriptome profile of P. xylostella larvae. The 'Oases' package was used to assemble data for differential expression analysis. Initially, reads from the parasitized and non-parasitized larvae were cleaned and combined, before de novo transcriptome assembly was carried out using Oases 0.1 .18 . [32]. The individual sets of reads were then mapped back to the previously assembled contigs and counted as a proxy for gene expression. After filtering our dataset using criteria such as number of reads, contig length, E-value (for nearest homolog identity) and greater than 2-fold change, 928 contigs were shortlisted. Figure 4 shows that most of the differentially expressed transcripts for the selected GO terms (Level 2 ), molecular function and biological process, were upregulated. Among the contigs, only those related to immunity and development, which were differentially transcribed after $D$. semiclausum parasitization, are displayed in Tables 2 and 3, respectively, since these are the genes most relevant to parasitism. In instances where differential expression of $P$. xylostella genes following $D$. semiclausum parasitization may not be consistent with proteomic observations in other hostparasitoid systems previously reported (e.g. [2]), it is 


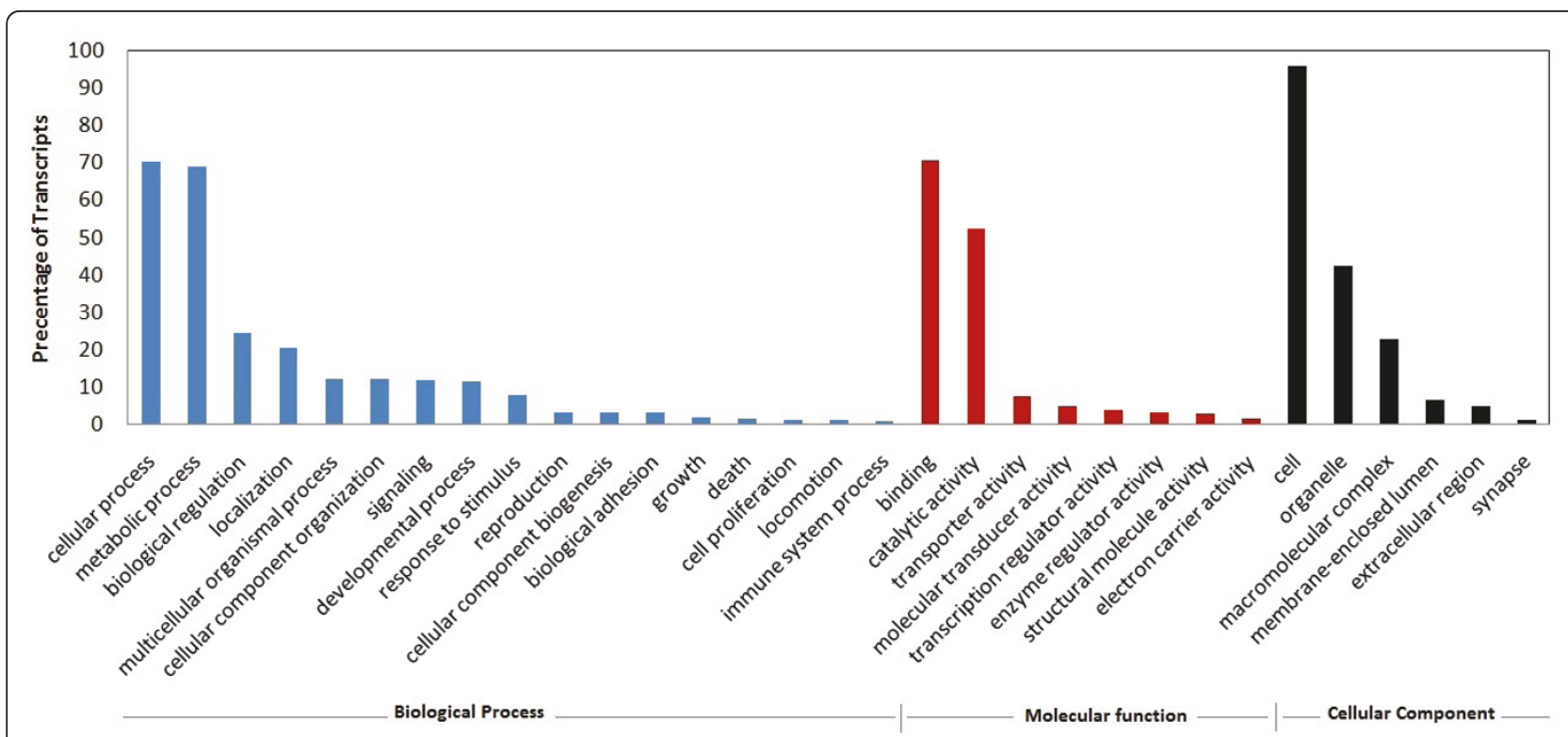

Figure 2 GO annotation of consensus sequences (Level 2). 20704 sequences were annotated by B2GO software. This program categorized 14075 contigs in biological process, 18127 contigs in molecular function and 10048 contigs in cellular components. The data from InterPro terms, EC codes and KEGG were merged with GO terms for a wide functional range cover in B2GO annotation.

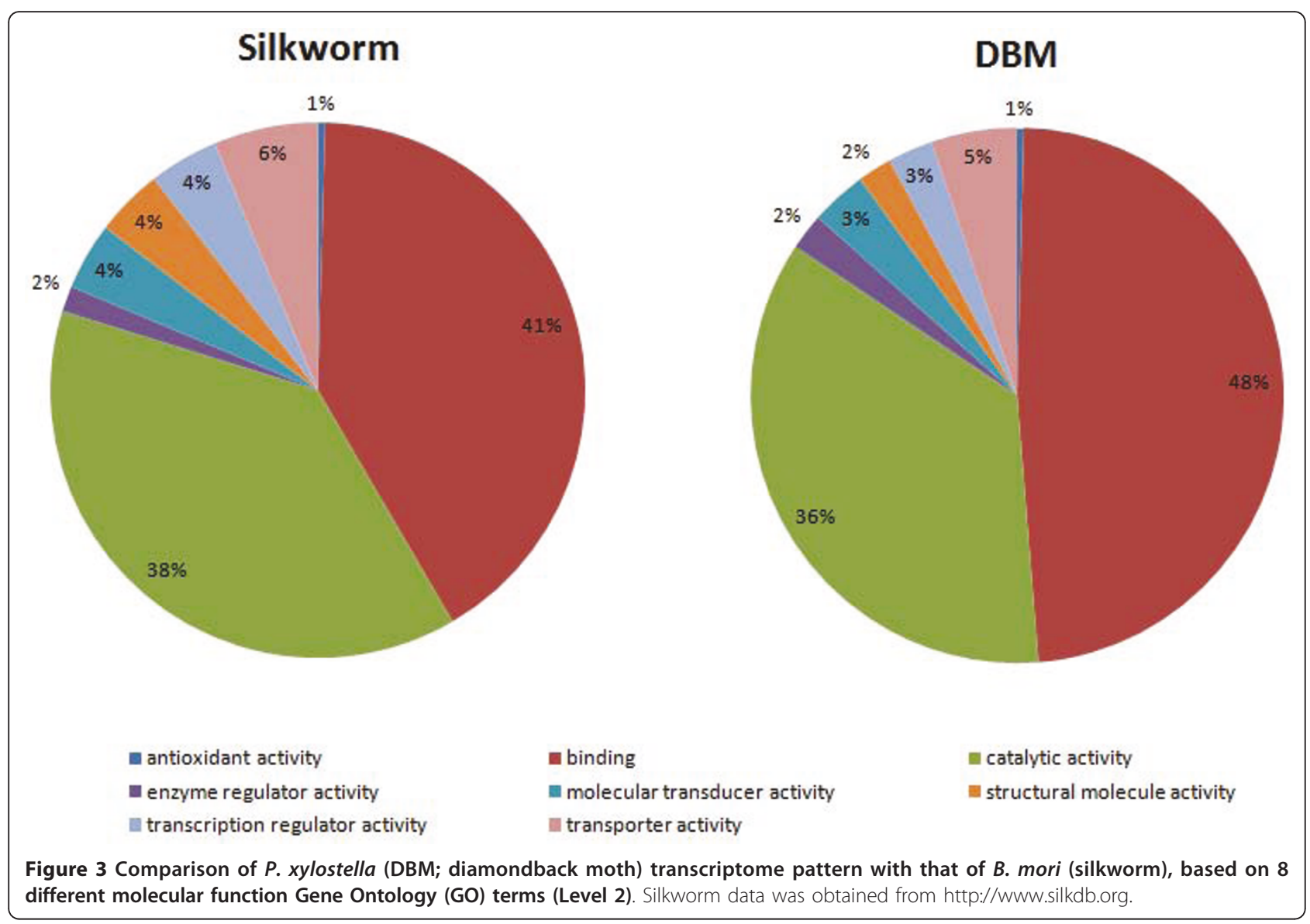


possible that post-transcriptional inhibitory effects of parasitoids' maternal factors (e.g. PDVs or venom) contribute to these differences. It has been reported that PDV genes are able to interrupt translation of host genes with their host translation inhibitory factors (HTIF) which was initially characterized from Campoletis sonorensis IV (CsIV) [33]. Accordingly, in Heliothis virescens it was shown that lysozyme activity declined after parasitization by $C$. sonorensis or injection of CsIV; however, the transcript levels of the gene increased after parasitization. This suggested that CsIV may regulate host cell gene expression at the translation level. We also found that lysozyme transcript levels increased following parasitization (Table 2). Another study also showed that lysozyme concentration and activity in $P$. xylostella larvae parasitized by Cotesia plutellae was decreased [2]; however, transcript levels were not measured. Recently, Barandoc and Kim [34] showed that the translation of storage protein in $P$. xylostella was inhibited by two BV genes (CpBV15 $\alpha$ and CpBV15 $\beta$ ). In another study, it was shown that expression of antimicrobial peptides (diptericin, cecropin A and drosomycin) were either unchanged or minimally induced in parasitized Drosophila melanogaster larvae by Leptopilina boulardi [35]. The authors concluded that antimicrobial genes are regulated differently independent of those mediating cellular encapsulation.

In addition to post-transcriptional effects of PDV infection, there may also be variations in different hostparasitoid interactions with regard to host transcripts affected by parasitization/PDV infection. In a very recent study, it was shown that in Spodoptera frugiperda larvae injected with Hyposoter didymator ichnovirus (HdIV) or Microplitis demolitor bracovirus $(M d \mathrm{BV})$, the differentially expressed transcripts in hemocytes and fat body largely differed depending on the PDV injected suggesting that the tissues responded differently to the different viruses [36]. However, there were a number of host genes that responded similarly when infected with $H d \mathrm{IV}$ or $M d \mathrm{BV}$. Based on this study, $H d \mathrm{IV}$ affected transcript levels in both hemocytes and fat body, whereas $M d \mathrm{BV}$ mostly affected gene expression in the fat body.

In our study, we found that antimicrobial peptides such as gloverin, moricin, lysozyme II and cecropin were up-regulated after parasitoid attack, compared to transcription levels in control unparasitized larvae. Among these, lysozyme II and gloverin had the highest transcription levels in parasitized $P$. xylostella larvae relative to other antimicrobial peptides (Figure 5; Table 2). Transcription levels for cecropin 1 and pxCecropin $\mathrm{E}$ increased by more than 3 -fold after $D$. semiclausum attack (Table 2). It has been reported that immunerelated genes were also up-regulated in P. xylostella larvae in response to microbial challenge (e.g. pxCecropin
5.94 fold, hemolin 3.18 fold and cecropin E 4.99 fold) [37]. Barandoc et al. measured pxCecropin expression levels by quantitative RT-PCR (qRT-PCR) in parasitized P. xylostella larvae and showed that pxCecropin was suppressed by C. plutellae BV [12]. Some antimicrobial peptides, such as moricin and gloverin, were previously found not to be induced by bacterial challenge of lepidopteran larvae, while lysozyme and cecropins are wellknown inducible antimicrobial peptides [12,38]. Recently, it has been reported that gloverin expression was changed after bacterial infection in P. xylostella [39]. Our data shows that immune responses after parasitoid attack appear to be different from microbial challenge responses, because gloverin and moricin-like peptide were up-regulated about 7 and 11 fold, respectively, after D. semiclausum attack.

Other related genes which were up-regulated in parasitized larvae included a serine protease and serine protease inhibitor (pxSerpin 3) (Table 2). Serine proteases are major immune regulatory proteins, which are found in a wide range of species from insects to mammals. In contrast, a proteomics analysis showed that pxSerpin 2 was suppressed in P. xylostella larval plasma during parasitism by C. plutellae [7]. Beck et al. demonstrated that the ovarian calyx fluid of the ichneumonid endoparasitoid Venturia canescens has the potential to suppress the host immune system due to a putative serpin activity [40]. Here, we found that serine protease inhibitors (JL943746, JL943748, JL943775, JL943864) were over-expressed two- to seven-fold, after parasitism in $P$. xylostella. Thus, the induction of serine protease inhibitors upon immune challenge in parasitized larvae could be part of an endoparasitoid immune suppressive strategy. Many insect protease inhibitors are known to inactivate enzymes isolated from entomopathogenic fungi, and their involvement in insect-pathogen interactions has been widely postulated [41]. Aguilar et al. reported that five serine proteases involved in a single metabolic cascade were up-regulated in Anopheles gambiae upon microbial challenge, but they suggested a role for the proteases in protecting the mosquito from detrimental effects of an uncontrolled spread of immune reaction [42].

Serine proteases also play a significant role in the activation of the prophenoloxidase (proPO) cascade. In insects, proPO is activated upon injury or invasion, which results in localized melanization of the wound area and/or melanotic capsules capturing invading microorganisms and parasites [43]. In the current study, proPO activating protease (PAP) transcription was upregulated in parasitized larvae of $P$. xylostella. In a genome-wide microarray study of $D$. melanogaster, several genes encoding enzymes of the melanization cascade were found to be up-regulated by $L$. boulardi 


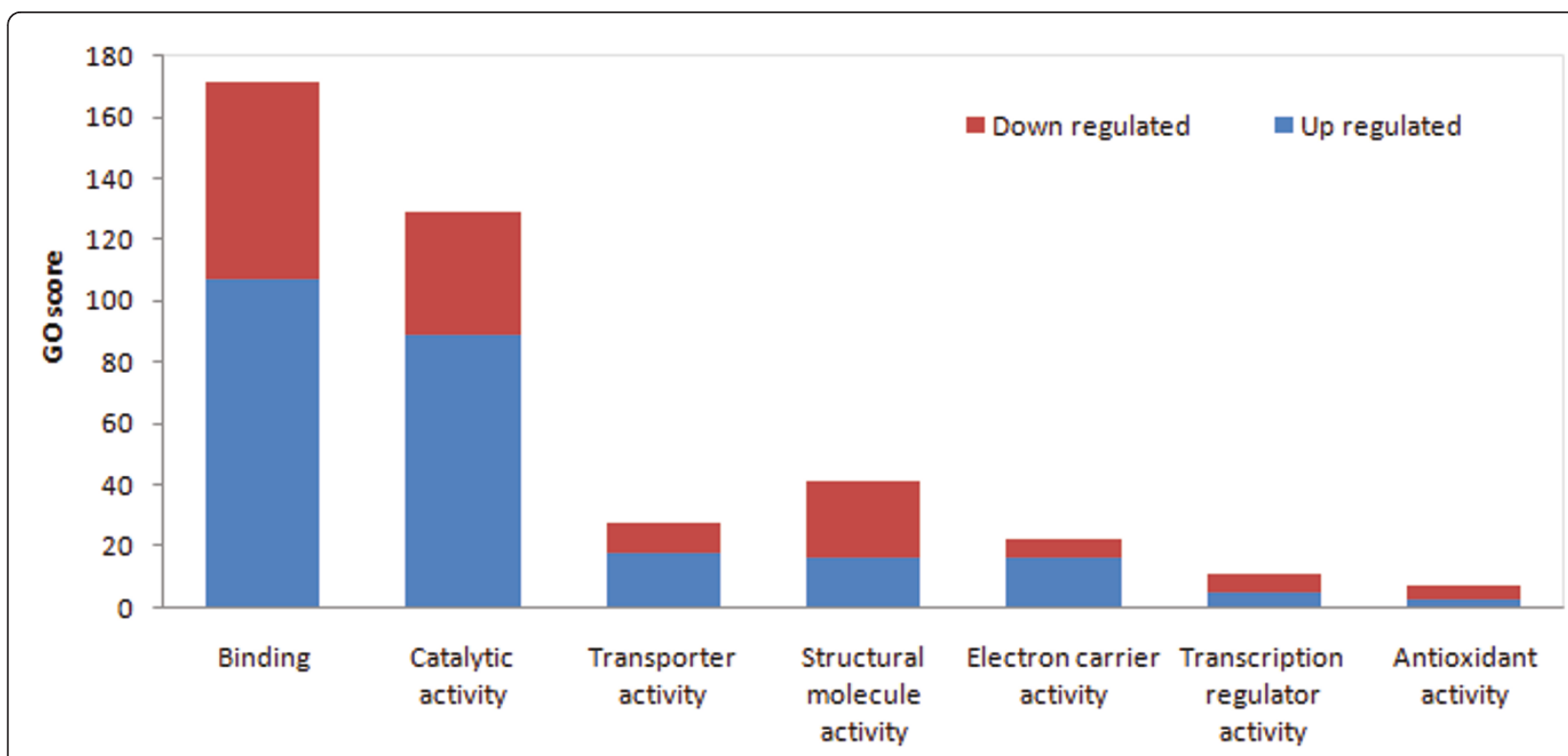

GO Terms for Molecular Function (Level 2)

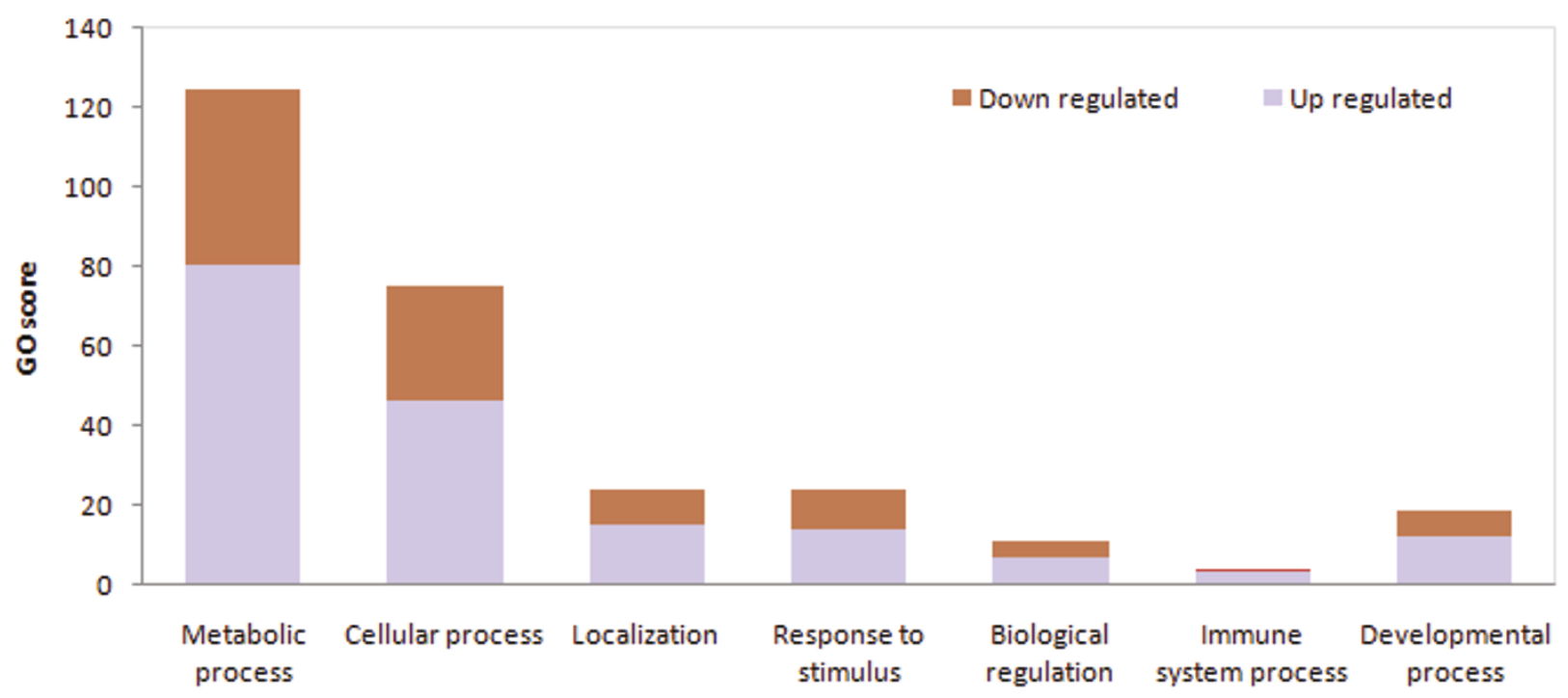

GO Terms for Biological Process (Level 2)

Figure 4 The gene ontology score for some selected GO terms (level 2) for significantly up- and down-regulated transcripts. (A) Molecular Function (B) Biological Process. Binding and catalytic activity had the highest GO scores for Molecular Function among those genes that were differentially expressed after parasitization. In the Biological Process category, two GO terms of metabolic and cellular processes showed the highest GO scores. In each group, the abundance of up-regulated genes was higher than down-regulated genes.

parasitization [44], consistent with this study. Asgari et al. (2003) reported that venom protein (Vn50) from Cotesia rubecula is homologous to serine protease homologs [43]. It is likely that the injection of this protein (or putative homologs thereof) by parasitoid wasps into the host body, may interfere with the proteolytic cascade that leads to the activation of proPO. cDNA microarray analysis of $S$. frugiperda hemocytes and fat body 24 hours after injection of $H d I V$ revealed differential expression of several host genes [45]. Among these, eight immune-related genes showed differential expression in hemocytes with proPO-1 and proPO-2 showing up-regulation, while PAP transcript levels declined. Other immune-related genes that were differentially expressed in the hemocytes were galectin, which showed up-regulation, whereas scavenger R, immulectin-2, lysozyme and calreticulin showed down-regulation [45]. A recent study confirmed up-regulation of proPOs 
Table 2 A list of $P$.xylostella immune-related genes that were differentially transcribed after parasitization by $D$. semiclausum

\begin{tabular}{|c|c|c|c|c|c|c|c|c|}
\hline $\begin{array}{l}\text { Sequence } \\
\text { ID }\end{array}$ & $\begin{array}{l}\text { TSA Accession } \\
\text { No. }\end{array}$ & $\begin{array}{c}\text { Nt. } \\
\text { Length }\end{array}$ & $\begin{array}{l}\text { Fold } \\
\text { change }\end{array}$ & Protein & Species & E value & $\begin{array}{l}\text { Nt. ID } \\
(\%)\end{array}$ & Accession no. \\
\hline Locus 2992 & JL943792 & 517 & 11 & Moricin-like peptide C2 & Galleria mellonella & $5.00 \mathrm{E}-12$ & 75 & ABQ42576.1 \\
\hline Locus 11864 & JL943746 & 452 & 7.06 & Serine proteinase inhibitor & $\begin{array}{l}\text { Procambarus } \\
\text { clarkii }\end{array}$ & 5.00E-14 & 41 & AAQ22771.1 \\
\hline Locus 13987 & JL943753 & 281 & 6.97 & Gloverin & Plutella xylostella & $3.00 \mathrm{E}-49$ & 100 & ACM69342.1 \\
\hline Locus 42625 & JL943821 & 487 & 6.71 & $\begin{array}{l}\text { Beta-1,3-glucan recognition } \\
\text { protein } 3\end{array}$ & $\begin{array}{l}\text { Helicoverpa } \\
\text { armigera }\end{array}$ & $5.00 \mathrm{E}-30$ & 45 & ACl32828.1 \\
\hline Locus 652 & JL943855 & 803 & 6.25 & Proline-rich protein & Galleria mellonella & $6.00 \mathrm{E}-18$ & 38 & ACQ99193.1 \\
\hline Locus 10530 & JL943744 & 1440 & 6.09 & Transferrin & Plutella xylostella & 0 & 99 & BAF36818.1 \\
\hline Locus 19881 & JL943772 & 503 & 4.96 & Odorant binding protein & Heliothis virescens & 1.00E-49 & 66 & ACX53743.1 \\
\hline Locus 8118 & JL943865 & 992 & 4.51 & Serine proteinase & $\begin{array}{l}\text { Samia cynthia } \\
\text { ricini }\end{array}$ & $6.00 \mathrm{E}-89$ & 55 & BAF43531.1 \\
\hline Locus 4070 & JL943818 & 449 & 4.37 & Cecropin $\mathrm{E}$ & Plutella xylostella & 8.00E-17 & 100 & BAF36816.1 \\
\hline Locus 6056 & JL943850 & 650 & 4.3 & Cecropin 1 (antibacterial peptide) & Plutella xylostella & $1.00 \mathrm{E}-16$ & 98 & ADA13281.1 \\
\hline Locus 2740 & JL943785 & 349 & 4.23 & Thrombin inhibitor infestin & Triatoma infestans & 7.00E-19 & 47 & AAK57342.1 \\
\hline Locus 742 & JL943860 & 1405 & 3.99 & Lysozyme ॥ & Artogeia rapae & 4.00E-15 & 76 & AAT94286.1 \\
\hline Locus 8845 & JL943866 & 517 & 3.81 & Peptidoglycan recognition protein & Plutella xylostella & 2.00E-86 & 97 & BAF36823.1 \\
\hline Locus 3377 & JL943803 & 744 & 3.78 & $\begin{array}{l}\text { Peptidoglycan recognition protein } \\
\text { S6 }\end{array}$ & Bombyx mori & 3.00E-58 & 61 & NP_001036858.1 \\
\hline Locus 5206 & JL943842 & 712 & 3.67 & Hemolin & Plutella xylostella & $\begin{array}{l}7.00 \mathrm{E}- \\
131\end{array}$ & 97 & ACN69054.1 \\
\hline Locus 11896 & JL943747 & 1453 & 3.28 & $\begin{array}{l}\text { Prophenoloxidase-activating } \\
\text { proteinase } 3\end{array}$ & Plutella xylostella & 0 & 93 & BAF36824.1 \\
\hline Locus 4541 & JL943828 & 843 & 3 & Trypsin-like serine proteinase 1 & Plutella xylostella & $2.00 \mathrm{E}-37$ & 42 & ADK66277.1 \\
\hline Locus 3869 & JL943816 & 1604 & 2.91 & Bifunctional protein folD & $\begin{array}{l}\text { Culex } \\
\text { quinquefasciatus }\end{array}$ & $\begin{array}{l}2.00 \mathrm{E}- \\
101\end{array}$ & 63 & XP_001846734.1 \\
\hline Locus 30146 & JL943795 & 236 & 2.91 & Nucleotide excision repair protein & Bombyx mori & 1.00E-28 & 71 & NP_001177140.1 \\
\hline Locus 14548 & JL943754 & 580 & 2.87 & $\begin{array}{l}\text { Beta-1,3-glucan recognition } \\
\text { protein } 2\end{array}$ & Bombyx mori & $5.00 \mathrm{E}-40$ & 49 & NP_001037450.1 \\
\hline Locus 15717 & JL943757 & 333 & 2.73 & $\begin{array}{l}\text { Prophenoloxidase activating factor } \\
3\end{array}$ & Bombyx mori & 3.00E-19 & 57 & AAL31707.1 \\
\hline Locus 13921 & JL943752 & 602 & 2.68 & Serine protease 33 & $\begin{array}{l}\text { Mamestra } \\
\text { configurata }\end{array}$ & $2.00 \mathrm{E}-36$ & 50 & ACR15983.2 \\
\hline Locus 12724 & JL943748 & 1288 & 2.51 & Serine protease inhibitor 7 & Bombyx mori & 5.00E-94 & 46 & NP_001139701.1 \\
\hline Locus 43519 & JL943823 & 256 & 2.5 & Ceramidase & Aedes aegypti & 2.00E-21 & 62 & XP_001658093.1 \\
\hline Locus 48995 & JL943836 & 207 & 2.5 & Toll receptor & $\begin{array}{l}\text { Tribolium } \\
\text { castaneum }\end{array}$ & 2.00E-19 & 59 & XP_971999.1 \\
\hline Locus 1006 & JL943743 & 1154 & 2.41 & Lipocalin & Bombus ignitus & 1.00E-89 & 64 & ADA82597.1 \\
\hline Locus 6114 & JL943851 & 1293 & 2.38 & Lysosomal acid lipase & $\begin{array}{l}\text { Tribolium } \\
\text { castaneum }\end{array}$ & $1.00 \mathrm{E}-65$ & 39 & XP_972957.2 \\
\hline Locus 28994 & JL943788 & 911 & 2.33 & $\begin{array}{l}\text { Pattern recognition serine } \\
\text { proteinase }\end{array}$ & Manduca sexta & 3.00E-87 & 51 & AAR29602.1 \\
\hline Locus 20345 & JL943774 & 322 & 2.26 & Trypsin T6 & Heliothis virescens & $9 \mathrm{E}-16$ & 54 & ABR88249.1 \\
\hline Locus 17873 & JL943765 & 412 & 2.25 & $\mathrm{NADP}+$ & Danio rerio & $1.00 \mathrm{E}-56$ & 76 & NP_998058.1 \\
\hline Locus 7994 & JL943864 & 1305 & 2.24 & $\begin{array}{l}\text { Serine protease inhibitor (pxSerpin } \\
\text { 3) }\end{array}$ & Plutella xylostella & 2.00E-99 & 50 & BAF36821.1 \\
\hline Locus 2093 & JL943776 & 2890 & 2.21 & Apolipophorins & Manduca sexta & 0 & 67 & Q25490.1 \\
\hline Locus 20404 & JL943775 & 251 & 2.19 & $\begin{array}{l}\text { Serine protease inhibitor (Serpin } \\
\text { 13) }\end{array}$ & Bombyx mori & 4.00E-14 & 49 & NP_001139705.1 \\
\hline Locus 41604 & JL943819 & 282 & 2.16 & Broad-Complex isoform Z2 & Bombyx mori & $1.00 \mathrm{E}-30$ & 98 & BAD24051.1 \\
\hline Locus 35475 & JL943806 & 363 & 2.15 & Heat Shock Protein (HSP70) & $\begin{array}{l}\text { Acyrthosiphon } \\
\text { pisum }\end{array}$ & $3.00 \mathrm{E}-12$ & 44 & XP_001950064.1 \\
\hline Locus 29819 & JL943791 & 461 & 2.14 & $\begin{array}{l}\text { Beta-1,3-glucan recognition } \\
\text { protein 2a }\end{array}$ & $\begin{array}{l}\text { Helicoverpa } \\
\text { armigera }\end{array}$ & 1.00E-53 & 64 & ACI32826.1 \\
\hline Locus 4518 & JL943827 & 303 & 2.13 & Serine protease 1 & Lonomia obliqua & 4.00E-22 & 51 & AAV91432.2 \\
\hline
\end{tabular}


Table 2 A list of $P$.xylostella immune-related genes that were differentially transcribed after parasitization by $D$. semiclausum (Continued)

\begin{tabular}{|c|c|c|c|c|c|c|c|c|}
\hline Locus 39662 & J 943817 & 299 & 2.12 & $\begin{array}{l}\text { 1-phosphatidylinositol-4,5- } \\
\text { bisphosphate }\end{array}$ & Bombyx mori & $6.00 \mathrm{E}-45$ & 86 & NP_001165393.1 \\
\hline Locus 9824 & JL943870 & 627 & 2.11 & $\begin{array}{l}\text { Peripheral-type benzodiazepine } \\
\text { receptor }\end{array}$ & Bombyx mori & $6.00 \mathrm{E}-34$ & 57 & NP_001040343.1 \\
\hline Locus 19848 & JL943771 & 1136 & 2.1 & Peroxidasin & $\begin{array}{l}\text { Tribolium } \\
\text { castaneum }\end{array}$ & $\begin{array}{l}1.00 \mathrm{E}- \\
134\end{array}$ & 62 & XP_968570.1 \\
\hline Locus 21658 & JL943781 & 437 & 2.04 & Hemolymph proteinase 8 & Manduca sexta & $4 \mathrm{E}-49$ & 71 & AAV91006.1 \\
\hline Locus 620 & JL943852 & 1032 & -2 & Heat Shock Protein (HSP90) & Plutella xylostella & $\begin{array}{l}8.00 \mathrm{E}- \\
140\end{array}$ & 100 & BAE48742.1 \\
\hline Locus 18755 & JL943766 & 351 & -2.06 & Vasorin & $\begin{array}{l}\text { Culex } \\
\text { quinquefasciatus }\end{array}$ & $1.00 \mathrm{E}-54$ & 85 & XP_001870087.1 \\
\hline Locus 15108 & JL943755 & 615 & -2.07 & Arylalkylamine $\mathrm{N}$-acetyltransferase & Antheraea pernyi & $1.00 \mathrm{E}-29$ & 38 & ABD17803.1 \\
\hline Locus 19225 & JL943768 & 253 & -2.12 & Flap endonuclease & Carukia barnesi & $6.00 \mathrm{E}-25$ & 83 & ACY74444.1 \\
\hline Locus 29249 & J2943789 & 213 & -2.12 & Putative lysozyme & Bombyx mori & 4.00E-22 & 67 & ADA67927.1 \\
\hline Locus 7618 & JL943861 & 3056 & -2.14 & Fascin & $\begin{array}{l}\text { Tribolium } \\
\text { castaneum }\end{array}$ & 0 & 79 & XP_972494.1 \\
\hline Locus 13139 & J 943751 & 701 & -2.4 & Hemocyte protease-1 & Bombyx mori & $6 \mathrm{E}-75$ & 60 & BAG70409.1 \\
\hline Locus 11481 & JL943873 & 364 & -3.25 & Trypsin & $\begin{array}{l}\text { Helicoverpa } \\
\text { armigera }\end{array}$ & $5 \mathrm{E}-16$ & 43 & ACB54939.1 \\
\hline Locus 24418 & J'943783 & 211 & -3.5 & Black (DOPA-deC-like) & Papilio xuthus & $1.00 \mathrm{E}-29$ & 87 & BAl87832.1 \\
\hline Locus 536 & JL943843 & 527 & -3.65 & Catalase & Takifugu obscurus & $1.00 \mathrm{E}-17$ & 35 & ABV24056.1 \\
\hline Locus 3343 & JL943800 & 289 & -3.78 & Immune-related Hdd1 & Hyphantria cunea & $3.00 \mathrm{E}-11$ & 39 & AAD09279.1 \\
\hline Locus 13049 & JL943750 & 452 & -5.81 & Putative defense protein Hdd11 & Hyphantria cunea & $8.00 \mathrm{E}-55$ & 67 & 096382.1 \\
\hline
\end{tabular}

Fold changes were generated by comparing average read depths for each contig.

in S. frugiperda larvae injected with $H d \mathrm{IV}$; however, in the same host injected with $M d \mathrm{BV}$, proPO transcript levels declined [36] which suggested differential responses of the host to different PDVs.

Transcripts of most proteins, which are involved in the Toll pathway such as Relish, Dorsal, Pelle, Cactus and Toll receptor, were found in our deep sequencing analysis, but only transcription levels of proteins that showed similarity to the Toll receptor were up-regulated (2.5 fold; Table 2). In D. melanogaster larvae parasitized by Asobara tabida or L. boulardi, components of the Toll/Imd (Immune deficiency) pathways were up-regulated, and antimicrobial peptide expression was increased $[44,46]$. In addition, in Drosophila, Toll and Imd pathways are required for activation and stimulation of NF- $\kappa$ Bs signal transduction and also responsible for innate immune response in parasitized Drosophila [47]. NF- $\kappa$ B proteins are a family of proteins in eukaryotes that are involved in the control of a large number of cellular and organismal processes, such as immune responses, developmental processes, cellular growth, and apoptosis. Furthermore, NF- $\kappa$ B signalling is important in immune inducibility of pathogen-associated-molecular-patterns, and it is widely assumed that it plays a conserved role in invertebrate immune regulation $[48,49]$.

It has been suggested that PDV-expressed vankyrin proteins may interfere with NF- $\kappa \mathrm{B}$-mediated signalling during immune response and development in parasitized larvae [15,50]. Fath-Goodin et al. (2009) reported that CsIV vankyrin genes also encode proteins with sequence homology to the inhibitory domains of NF- $\kappa \mathrm{B}$ transcription factor inhibitors [13].

The results of our transcriptome analysis also indicated that genes known to be involved in insecticide resistance/detoxification are up-regulated following parasitism (Table 2). In agreement, it has previously been reported that cytochrome P450 (CYP) and glutathione-S-transferase (GST) activities increased in parasitized P. xylostella larvae [29]. Takeda et al. (2006) suggested that parasitoid larvae contributed to CYP activity enhancement since the parasitoid hatched two days after oviposition and the CYP activity was significantly increased three days after parasitization [29].

Our analyses also detected a considerable number of other immune-related genes whose transcription levels altered after parasitization by D. semiclausum. However, only a small group affected by parasitoid attack were found to be altered enough to be statistically biologically relevant (i.e. showing greater than two-fold change).

\section{Transcription levels of host development-related genes}

Generally, larval endoparasitoids lay their eggs into the host hemocoel, and their progenies develop by consuming host hemolymph and tissues. As a consequence, the parasitoid's larval growth also fully depends on the host's development $[1,51,52]$. In $P$. xylostella larvae 
parasitized by D. semiclausum, development is arrested at the prepupal stage [53]. Developmental arrest before pupation is one of the most common effects of PDVs and/or other maternal factors injected by many endoparasitoids into their hosts [14,54-56]. In these interactions, the parasitoid larvae and PDVs are responsible for increasing the juvenile hormone $(\mathrm{JH})$ titre in host larvae and preventing ecdysteroid levels from rising sufficiently to allow host pupation [57-61].

Based on our transcriptome data, parasitism by $D$. semiclausum leads to down-regulation of genes associated with ecdysteroid activities; for example, the transcription level of ecdysteroid regulated protein was down-regulated more than 26 times in parasitized larvae (Table 3). Considering that ecdysteroids are required to trigger expression of ecdysteroid regulated protein [62], and that parasitism in general leads to reductions in ecdysteroid titres [54,63-66], down-regulation of ecdysteroid regulated protein is expected.

Juvenile hormone binding protein (JHBP) may protect $\mathrm{JH}$ from non-specific degradation and adsorption by preventing exposure of $\mathrm{JH}$ to epoxide hydration by $\mathrm{JH}$ epoxide hydrolase (JHEH), which generates the hormonally inactive $\mathrm{JH}$ diol [67]. In agreement, JHBP transcript levels were up-regulated more than 2 times and interestingly, transcription levels of JHEH were down-regulated more than 2 times (Table 3). In all the reported hostparasitoid systems, it seems that $\mathrm{JH}$ is maintained at high levels during parasitoid larval development $[58,66,68]$. Therefore, an increase in JHBP, and corresponding decrease in JHEH transcription levels, after parasitism, seems logical to maintain higher $\mathrm{JH}$ levels during parasitism.

As indicated above, previous studies have shown that PDVs may inhibit translation of specific storage or growth-associated proteins despite up-regulation (or steady-state) of transcript levels of the encoding genes, following parasitism or injection of PDVs [69-71]. In this study, we found that arylphorin and methioninerich storage proteins were over-transcribed in parasitized larvae (Table 3); however, their translation may be affected similarly to mechanisms in the reports discussed above, which needs to be experimentally shown.

\section{Quantitative RT-PCR validation of transcriptome analysis}

To validate our deep sequencing data, nine differentially regulated $P$. xylostella genes were selected from immuneand development-related genes (Tables 2 and 3) for qRTPCR analysis, using the same RNA samples as for deep sequencing. These were cuticle protein, ecdysteroid regulated protein, $\mathrm{JH}$ epoxide hydrolase, insulin receptor, methionine-rich storage protein 1 , gloverin, hemolin, pxSerpin 3 and Toll receptor. The qRT-PCR results confirmed the data obtained from deep sequencing analysis showing similar trends in up- or down-regulation of host genes (Figure 6). For example, based on deep sequencing analysis, gloverin, Toll receptor, and pxSerpin 3 were upregulated 6.9, 2.5 and 2.2 fold, respectively (Table 2), and showed 5.5, 2.6 and 2.7 fold changes, respectively in qRT-PCR analyses (Figure 6).

Since the samples analysed above were pools of RNA from various time points, and it is known that expression of host genes may vary at different periods after parasitization, we further isolated RNA from $2^{\text {nd }}$ instar P. xylostella larvae at 16, 24 and $48 \mathrm{hrs}$ after parasitization, and analyzed three associated genes by qRT-PCR. These were hemolin, gloverin and the ecdysteroid regulated protein. For each time point, a mixture of 10 larvae was used. As expected, there were fluctuations in the expression levels of these genes following parasitization (Figure 7). For example, gloverin expression was highly induced at 16 hrs after parasitization, subsequently declined at $24 \mathrm{hrs}$, and then further reduced to the same level as unparasitized larvae at $48 \mathrm{hrs}$ post-parasitization (Figure 7). Hemolin was only up-regulated at $48 \mathrm{hrs}$ after parasitization. Expression of ecdysteroid regulated protein was initially down-regulated at $16 \mathrm{hrs}$ after parasitization, but increased at 24 hrs before subsequently declining by 48 hrs post-parasitization (Figure 7).

\section{Diadegma semiclausum ichnovirus genes}

PDV genes are divided into three groups based on whether they are expressed in the carrier wasp (class I), the infected host larvae (class II) or both (class III) [72]. Among these genes, class II genes have received the greatest attention and have been studied more than other groups [73]. The genomes of some IVs, such as those found in the wasps C. sonorensis, C. chlorideae, Hyposoter fugitivus, $H$. didymator, and Tranosema rostrale, have been sequenced and resultant data are available on public databases $[21,72,74]$. Six conserved gene families: repeat element, cysteine motif, viral innexin, viral ankyrin, $\mathrm{N}$-family and the polar-residue-rich proteins (a newly defined putative family), have been reported in most IV genomes [72].

Here, expression of a range of DsIV genes were detected in parasitized larvae. In our analysis, 19 unique sequences were identified from five PDV gene families including vankyrin, viral innexin, repeat elements, cysteine-rich motif, and polar residue rich protein families (Table 4). In addition, five other putative virus protein sequences with unknown function were identified in parasitized larvae, and showed more than 50\% similarity with some parts of IV reference genomes, but no putative specific protein domain homologies were detected in their sequences (Table 4). The online open reading frame finder tool at the NCBI website http:// www.ncbi.nlm.nih.gov/projects/gorf was used for prediction of full-length sequences in DsIV genes and only 
Table 3 Developmental- and non-immune metabolism-related transcripts of $\boldsymbol{P}$. xylostella, which were differentially expressed after $D$. semiclausum parasitization

\begin{tabular}{|c|c|c|c|c|c|c|c|c|}
\hline $\begin{array}{l}\text { Sequence } \\
\text { ID }\end{array}$ & $\begin{array}{l}\text { TSA Accession } \\
\text { No. }\end{array}$ & $\begin{array}{c}\text { Nt. } \\
\text { Length }\end{array}$ & $\begin{array}{l}\text { Fold } \\
\text { change }\end{array}$ & Protein & Species & $\begin{array}{l}\mathrm{E} \\
\text { value }\end{array}$ & $\begin{array}{l}\text { Nt. } \\
\text { ID } \\
\text { (\%) }\end{array}$ & Accession no. \\
\hline $\begin{array}{l}\text { Locus } \\
29717\end{array}$ & JL943790 & 504 & 27.86 & Endonuclease-reverse transcriptase & Bombyx mori & $1 \mathrm{E}-46$ & 67 & ADI61832.1 \\
\hline Locus 3567 & JL943808 & 277 & 20.01 & Glucose dehydrogenase precursor & $\begin{array}{l}\text { Pediculus humanus } \\
\text { corporis }\end{array}$ & $1 \mathrm{E}-15$ & 52 & XP_002429706.1 \\
\hline Locus 784 & JL943863 & 1943 & 12.5 & Methionine-rich storage protein 1 & Plutella xylostella & 0 & 100 & BAF45385.1 \\
\hline $\begin{array}{l}\text { Locus } \\
50007\end{array}$ & JL943839 & 234 & 8.31 & Putative RecQ Helicase & Heliconius melpomene & $1 \mathrm{E}-11$ & 63 & $\mathrm{CBH} 09254.1$ \\
\hline Locus 3712 & JL943813 & 1744 & 7.8 & Methionine-rich storage protein 2 & Plutella xylostella & 0 & 100 & BAF45386.1 \\
\hline Locus 1098 & JL943745 & 724 & 4.4 & Arylphorin-like hexamerin-2 & Plutella xylostella & $\begin{array}{l}1 \mathrm{E}- \\
141\end{array}$ & 100 & BAF32562.1 \\
\hline Locus 9922 & JL943871 & 1790 & 4.31 & 44 kDa zymogen (serine protease) & Tenebrio molitor & $9 \mathrm{E}-61$ & 35 & BAG14262.1 \\
\hline Locus 2239 & JL943782 & 2186 & 3.46 & Methionine-rich storage protein & Spodoptera exigua & 0 & 59 & ABX55887.1 \\
\hline Locus 352 & JL943805 & 1023 & 3.43 & Arylphorin-like hexamerin-1 & Plutella xylostella & $\begin{array}{l}2 \mathrm{E}- \\
172\end{array}$ & 89 & BAF32561.1 \\
\hline Locus 5917 & JL943849 & 2338 & 3.4 & Phenylalanine hydroxylase & Papilio xuthus & 0 & 88 & BAE66652.1 \\
\hline $\begin{array}{l}\text { Locus } \\
42829\end{array}$ & JL943822 & 273 & 3.33 & Syntaxin & Culex quinquefasciatus & $3 \mathrm{E}-21$ & 60 & XP_001865470.1 \\
\hline Locus 1575 & JL943758 & 1738 & 3.12 & $\begin{array}{l}\text { Phosphoribosylaminoimidazole } \\
\text { carboxylase }\end{array}$ & Bombyx mori & 0 & 90 & NP_001040376.1 \\
\hline $\begin{array}{l}\text { Locus } \\
33387\end{array}$ & JL943799 & 375 & 3.11 & Insulin receptor & Bombyx mori & $3 \mathrm{E}-34$ & 59 & NP_001037011.1 \\
\hline $\begin{array}{l}\text { Locus } \\
47369\end{array}$ & JL943832 & 347 & 3 & Leucine-rich transmembrane protein & $\begin{array}{l}\text { Pediculus humanus } \\
\text { corporis }\end{array}$ & $1 \mathrm{E}-24$ & 60 & XP_002422869.1 \\
\hline Locus 7126 & JL943859 & 1075 & 2.98 & Sugar transporter 4 & Bombyx mori & $\begin{array}{l}2 \mathrm{E}- \\
104\end{array}$ & 64 & NP_001165395.1 \\
\hline $\begin{array}{l}\text { Locus } \\
35539\end{array}$ & JL943807 & 592 & 2.55 & Torso-like protein & Tribolium castaneum & $2 \mathrm{E}-31$ & 38 & NP_001107843.1 \\
\hline $\begin{array}{l}\text { Locus } \\
36082\end{array}$ & JL943809 & 735 & 2.44 & Reverse transcriptase & Aedes aegypti & $3 \mathrm{E}-36$ & 39 & AAZ15237.1 \\
\hline Locus 199 & JL943773 & 1588 & 2.4 & $\begin{array}{l}\text { S-adenosyl-L-homocysteine } \\
\text { hydrolase }\end{array}$ & Plutella xylostella & 0 & 100 & BAF36817.1 \\
\hline Locus 5556 & JL943845 & 1186 & 2.33 & Yellow-fa & Bombyx mori & $\begin{array}{l}4 \mathrm{E}- \\
141\end{array}$ & 69 & NP_001037424.1 \\
\hline Locus 4588 & JL943829 & 205 & 2.24 & Endoprotease FURIN & Spodoptera frugiperda & $4 \mathrm{E}-28$ & 87 & CAA93116.1 \\
\hline Locus 4894 & JL943835 & 861 & 2.24 & Lipase & Helicoverpa armigera & $3 \mathrm{E}-50$ & 54 & ACB54943.1 \\
\hline Locus 4689 & JL943830 & 2429 & 2.21 & Cathepsin $L$ precursor & Tribolium castaneum & 0 & 62 & NP_001164088.1 \\
\hline Locus 3008 & JL943793 & 950 & 2.21 & Hemolymph proteinase 5 & Manduca sexta & $\begin{array}{l}2 \mathrm{E}- \\
101\end{array}$ & 62 & AAV91003.1 \\
\hline $\begin{array}{l}\text { Locus } \\
20931\end{array}$ & JL943777 & 661 & 2.17 & Gamma-glutamyl transferase & Bombyx mori & $1 \mathrm{E}-62$ & 56 & NP_001165385.1 \\
\hline $\begin{array}{l}\text { Locus } \\
21405\end{array}$ & JL943780 & 705 & 2.14 & Juvenile hormone binding protein & Manduca sexta & $2 \mathrm{E}-27$ & 35 & AAB25736.2 \\
\hline Locus 3797 & JL943815 & 1653 & 2.13 & Imaginal disk growth factor & Plutella xylostella & 0 & 100 & BAF36822.1 \\
\hline Locus 5088 & JL943841 & 1476 & 2.12 & Cathepsin B-like cysteine proteinase & Spodoptera exigua & $\begin{array}{l}1 \mathrm{E}- \\
146\end{array}$ & 81 & ABK90823.1 \\
\hline Locus 1887 & JL943767 & 1872 & 2.1 & Cathepsin D isoform 1 & Tribolium castaneum & $\begin{array}{l}7 \mathrm{E}- \\
165\end{array}$ & 73 & XP_966517.1 \\
\hline $\begin{array}{l}\text { Locus } \\
47019\end{array}$ & JL943831 & 207 & 2.09 & DNA-binding protein Ewg putative & $\begin{array}{l}\text { Pediculus humanus } \\
\text { corporis }\end{array}$ & $3 \mathrm{E}-22$ & 93 & XP_002430412.1 \\
\hline $\begin{array}{l}\text { Locus } \\
16109\end{array}$ & JL943872 & 515 & 2.08 & Nesprin-1 & $\begin{array}{l}\text { Pediculus humanus } \\
\text { corporis }\end{array}$ & $3 E-26$ & 36 & XP_002427810.1 \\
\hline $\begin{array}{l}\text { Locus } \\
41758\end{array}$ & JL943820 & 222 & 2.06 & Neuroglian & Mythimna separata & $4 \mathrm{E}-29$ & 78 & BAI49425.1 \\
\hline Locus 6830 & JL943856 & 427 & 2.04 & Cytochrome P450 & Plutella xylostella & $2 \mathrm{E}-67$ & 96 & ABW34440.1 \\
\hline
\end{tabular}


Table 3 Developmental- and non-immune metabolism-related transcripts of $\boldsymbol{P}$. xylostella, which were differentially expressed after $D$. semiclausum parasitization (Continued)

\begin{tabular}{|c|c|c|c|c|c|c|c|c|}
\hline $\begin{array}{l}\text { Locus } \\
17556\end{array}$ & JL943762 & 1272 & 2.03 & Arginase & Bombyx mori & $\begin{array}{l}9 \mathrm{E}- \\
144\end{array}$ & 72 & BAH19308.1 \\
\hline $\begin{array}{l}\text { Locus } \\
25700\end{array}$ & JL943784 & 286 & -2.03 & Cytochrome P450 monooxygenase & Helicoverpa zea & $7 \mathrm{E}-16$ & 74 & AAM54723.1 \\
\hline Locus 7042 & JL943858 & 809 & -2.05 & Tyrosine transporter & Aedes aegypti & $2 \mathrm{E}-18$ & 76 & XP_001658764.1 \\
\hline Locus 4738 & JL943833 & 1359 & -2.07 & Collagen & Bombyx mori & $2 \mathrm{E}-23$ & 49 & CAA83002.1 \\
\hline Locus 3369 & JL943802 & 471 & -2.09 & Trypsin alkaline B & Manduca sexta & 7 E-37 & 71 & P35046.1 \\
\hline Locus 7004 & JL943857 & 696 & -2.13 & Cuticular protein glycine-rich 20 & Bombyx mori & $3 \mathrm{E}-15$ & 52 & NP_001166784.1 \\
\hline $\begin{array}{l}\text { Locus } \\
17043\end{array}$ & JL943761 & 237 & -2.13 & $\begin{array}{l}\text { Voltage \& ligand gated potassium } \\
\text { channel }\end{array}$ & Culex quinquefasciatus & $2 \mathrm{E}-15$ & 71 & XP_001853758.1 \\
\hline $\begin{array}{l}\text { Locus } \\
16717\end{array}$ & JL943760 & 1585 & -2.14 & Multidrug resistance protein 2 & Culex quinquefasciatus & $1 \mathrm{E}-93$ & 41 & XP_001866984.1 \\
\hline Locus 5571 & JL943846 & 389 & -2.19 & Sugar transporter & Aedes aegypti & $1 \mathrm{E}-11$ & 48 & XP_001652873.1 \\
\hline $\begin{array}{l}\text { Locus } \\
13022\end{array}$ & JL943749 & 216 & -2.36 & Ecdysis-triggering hormone & Manduca sexta & $2 \mathrm{E}-15$ & 65 & AAD45613.1 \\
\hline Locus 6441 & JL943853 & 661 & -2.43 & Retinol dehydratase & Spodoptera frugiperda & $1 \mathrm{E}-53$ & 58 & AAC47136.1 \\
\hline $\begin{array}{l}\text { Locus } \\
15939\end{array}$ & JL943759 & 279 & -2.46 & Cyclin-dependent kinase 2-like & $\begin{array}{l}\text { Saccoglossus } \\
\text { kowalevskii }\end{array}$ & $3 \mathrm{E}-23$ & 68 & XP_002740677.1 \\
\hline Locus 487 & JL943834 & 1615 & -2.56 & Glucosinolate sulphatase & Plutella xylostella & 0 & 64 & CAD33828.1 \\
\hline Locus 6512 & JL943854 & 484 & -2.57 & Phosphohistidine phosphatase & Bombyx mori & $3 E-45$ & 62 & NP_001040265.1 \\
\hline Locus 7636 & J 943862 & 454 & -2.7 & Reverse transcriptase & Ostrinia nubilalis & $3 E-39$ & 48 & ABO45231.1 \\
\hline $\begin{array}{l}\text { Locus } \\
33235\end{array}$ & JL943798 & 220 & -2.74 & Juvenile hormone epoxide hydrolase & Bombyx mori & $5 \mathrm{E}-18$ & 64 & NP_001159617.1 \\
\hline $\begin{array}{l}\text { Locus } \\
36575\end{array}$ & JL943812 & 209 & -2.83 & Lipase & Bombyx mori & $8 \mathrm{E}-12$ & 52 & ADA67928.1 \\
\hline Locus 5577 & J 943847 & 1813 & -2.9 & Chitinase & Plutella xylostella & 0 & 100 & ACU42267.1 \\
\hline Locus 4357 & JL943824 & 1009 & -3.21 & Cuticular protein RR-1 motif 10 & Bombyx mori & $1 E-56$ & 68 & NP_001166738.1 \\
\hline $\begin{array}{l}\text { Locus } \\
21088\end{array}$ & JL943778 & 247 & -3.25 & Carboxypeptidase M & Aedes aegypti & $1 \mathrm{E}-37$ & 83 & XP_001661307.1 \\
\hline Locus 2898 & JL943787 & 485 & -4.27 & Acheron & Manduca sexta & $1 \mathrm{E}-68$ & 88 & AF443827_1 \\
\hline Locus 5445 & J 943844 & 1708 & -8.82 & Urbain & Bombyx mori & $4 \mathrm{E}-24$ & 37 & NP_001139414.1 \\
\hline $\begin{array}{l}\text { Locus } \\
21299\end{array}$ & J 943779 & 290 & -15.5 & 37-kDa serine protease & Bombyx mori & $6 \mathrm{E}-41$ & 81 & NP_001128675.1 \\
\hline $\begin{array}{l}\text { Locus } \\
17795\end{array}$ & JL943764 & 363 & -24.01 & Cuticle protein & Aedes aegypti & $3 E-29$ & 67.78 & XP_001659461.1 \\
\hline Locus 8908 & JL943867 & 625 & -26.71 & Ecdysteroid regulated protein & Manduca sexta & $1 \mathrm{E}-12$ & 71 & AAA29312.1 \\
\hline
\end{tabular}

Fold changes were generated by comparing average read depths for each contig.

four of these genes are reported here as full-length (Table 4).

Presence of multiple sequences for each PDV gene family is common in other IVs and we identified four sequences with vankyrin domain and two viral innexin transcripts, which showed high similarity with $H$. fugitivus IV innexins (Table 4). Repeat element domains were also identified in six sequences with translated lengths of between 209-244 amino acids. Transcription levels (or gene expression values) were found to be different among different members within each gene family. Vankyrin 1 and repeat element 1 had the highest transcription levels in their respective families, and also relative to other DsIV genes (Figure 8).

Hierarchical cluster analysis of vankyrin gene sequences of all reported PDV vankyrins (protein sequences at
$\mathrm{NCBI}$ ) using a neighbour-joining algorithm, classified BVs and IVs into two major groups (Figure 9). All four DsIV vankyrins that were identified in this study have high similarities with other IVs and were distributed into four separate clusters indicating that these members of the ankyrin family possibly originated from different segments of the DsIV genome or at least there has been some ancient gene duplication and/or differential selection even if encoded on the same circle. In addition, the separate clustering of vankyrin genes suggests that they are not closely related, and therefore did not likely undergo recent duplication to form similar paralogs.

\section{Conclusion}

Overall, this study provides the first comprehensive analysis of the impact of a parasitoid wasp on its host 


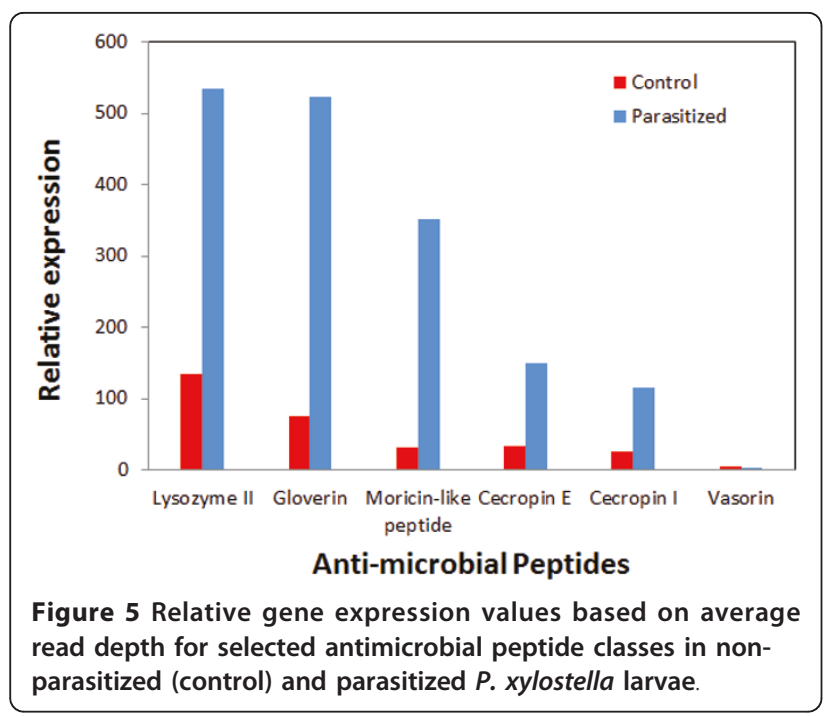

at the transcriptomic level, using RNA deep sequencing technique. The results showed differential expression of a large number of $P$. xylostella genes, including immune-related genes, upon parasitization by $D$. semiclausum. In addition, although presence of DsIV particles has been reported in parasitized larvae, our results provide evidence for expression of 19 DsIV genes expressed in the host, which have not been previously reported. Analysis of these sequences indicated the presence of conserved genes that belong to major IV class II genes. The transcriptome profiling data sets obtained in this study provide a basis for future research in this under-explored host-parasitoid interaction. In addition, the identified immune-, developmentand detoxification-related genes may be targets for $P$. xylostella control and allow manipulation of host-parasite interactions.

\section{Methods}

\section{Insects and parasitization}

P. xylostella and the parasitoid wasp (D. semiclausum) were raised on cabbage plants and host larvae, respectively, at $25^{\circ} \mathrm{C}$. Twenty five $3^{\text {rd }}$ and $4^{\text {th }}$ instar P. xylostella larvae each were exposed to wasps until parasitization was observed. Individual larvae that had been attacked by the parasitoid were collected and fed on fresh cabbage leaves. Larval samples were taken at
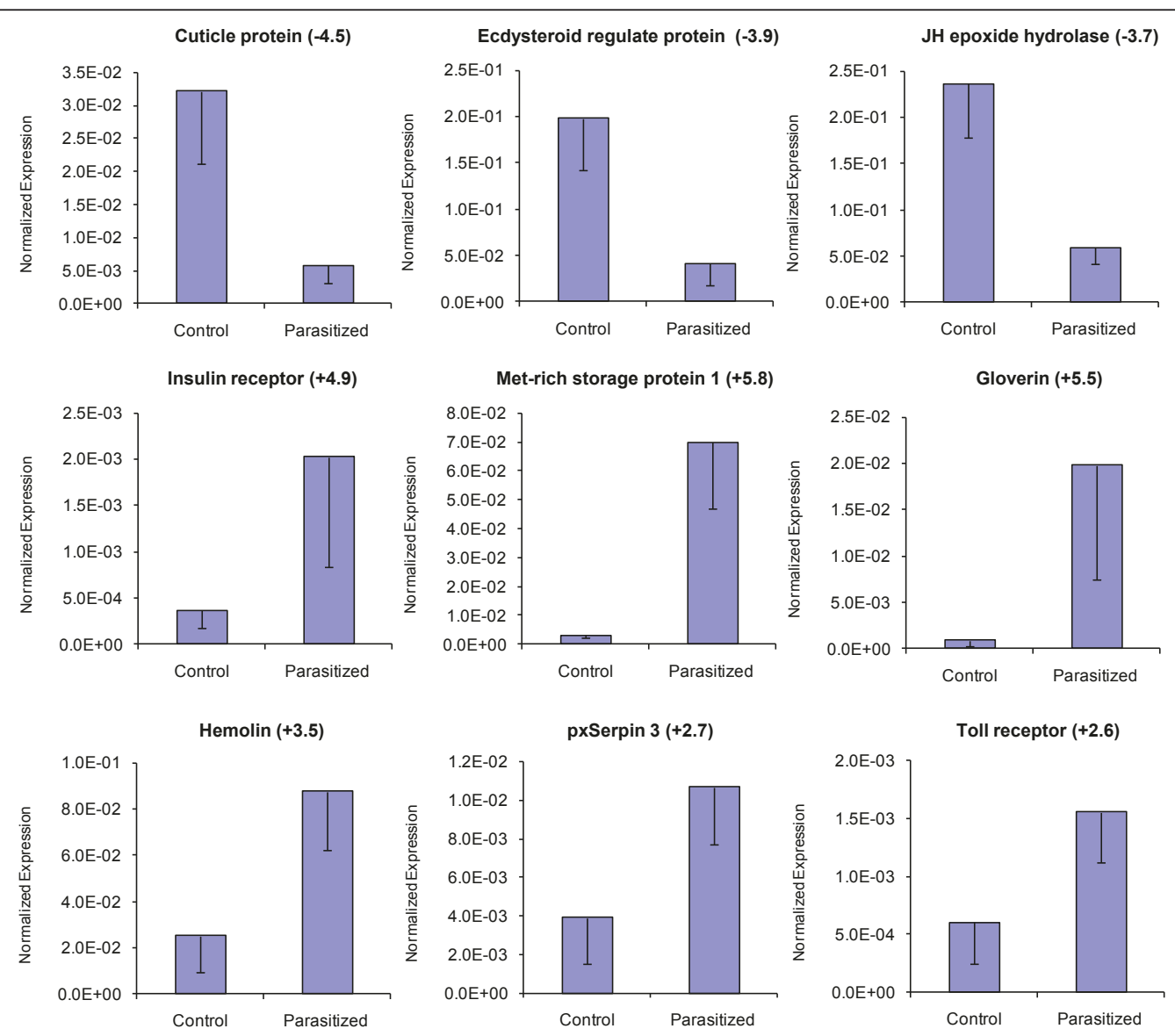

Figure 6 qRT-PCR analysis of nine selected genes from P. xylostella which showed differential expression after parasitization based on deep sequencing analysis. Error bars indicate standard deviations of averages from three replicates. Fold changes are shown in brackets. 


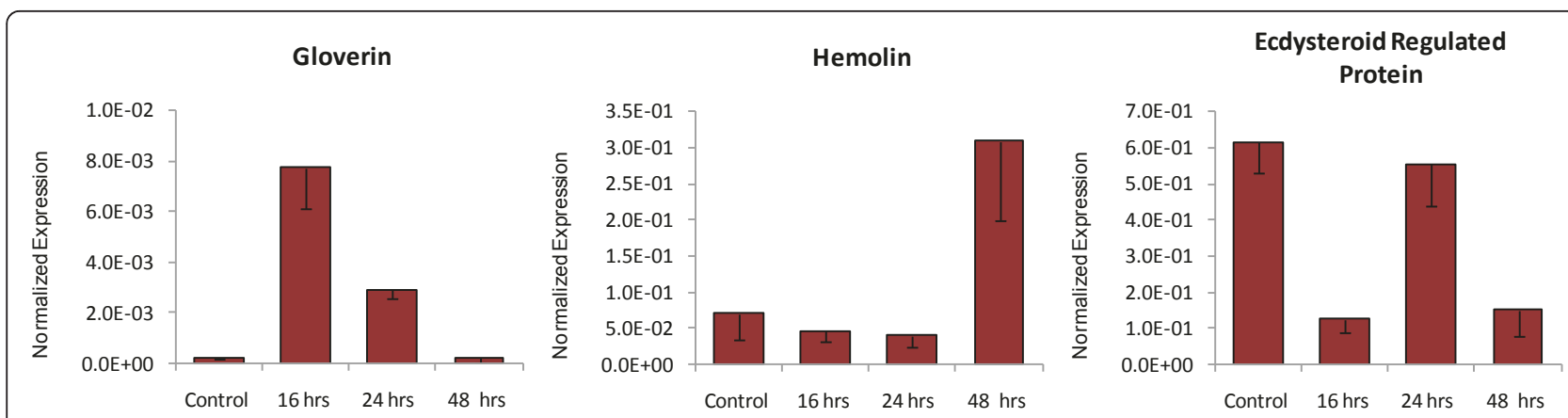

Figure 7 qRT-PCR analysis of expression levels of three selected genes in $2^{\text {nd }}$ instar $P$. xylostella larvae at three time points after parasitization with $D$. semiclausum, which showed differential expression after parasitization based on deep sequencing analysis. Error bars indicate standard deviations of averages from three replicates.

four different time intervals after parasitization $(6,12$, 24 and 48 hrs post-parasitization) and the samples were kept at $-80^{\circ} \mathrm{C}$ until RNA isolation. The same numbers of mixed larval instars $\left(3^{\text {rd }}\right.$ and $\left.4^{\text {th }}\right)$ of nonparasitized larvae were collected as the control treatment. It is worth mentioning that $P$. xylostella larvae parasitized at $3^{\text {rd }}$ instar continue to develop to $4^{\text {th }}$ instar.

\section{Sample preparation, deep sequencing and de novo transcriptome assembly}

Total RNA was extracted from all larval samples using Tri-Reagent ${ }^{\mathrm{TM}}$ (Molecular Research Center Inc.). RNA extracted from larvae at various time points post-parasitization were pooled and therefore temporal expression data was lost. This was also performed for non-parasitized samples. The pooled RNA sample concentrations were measured using a spectrophotometer and integrity was ensured through analysis on a $1 \%(\mathrm{w} / \mathrm{v})$ agarose gel. The samples with total concentration of 3.9 and $4.1 \mu \mathrm{g} /$ $\mu \mathrm{l}$ for parasitized and non-parasitized larvae, respectively, were used for cDNA library production.

The cDNA library was prepared by using $5 \mu \mathrm{g}$ of starting material for the Illumina mRNA Sequencing Sample preparation procedure (kit RS-930-1001). This involved purification and fragmentation of mRNA, first strand cDNA synthesis, second strand cDNA synthesis, end repair, addition of "A" bases to 3' ends, ligation of adapters, purification of ligated products, and PCR amplification to enrich cDNA templates. The library was validated, quantified and subjected to deep sequencing using a Genome Analyzer IIx Next generation sequencer on a 66 cycle single-end sequencing run, following the supplier's instructions (Geneworks, Adelaide). The GAII analyzer data were output as sequence tags of 65 bases. Sequence.txt files (in FASTQ format) were generated using Illumina Pipeline version 1.5.1. The CLC Genome Workbench (version 4.0.2) [75] algorithm for de novo sequence assembly was used to assemble contigs from a pooling of all the short-read data, using default parameters (similarity $=0.8$, length fraction $=$ 0.5 , insertion/deletion cost $=3$, mismatch cost $=3$ ).

\section{RNA sequence analysis}

The contigs arising from the de novo assembly were then used as a reference set of transcripts for RNAseq analysis. Short-read sequence data from parasitized and non-parasitized larvae were separately mapped against the reference set of assembled transcripts using the CLC Genome Workbench RNAseq function (min. length fraction $=0.9$, maximum mismatches $=2$ ). The relative transcript levels were output as RPKM (Reads Per Kilobase of exon model per Million mapped reads) values, which take into account the relative size of the transcripts and only uses the mapped-read datasets (i.e. excludes the non-mapped reads), to determine relative transcript abundance. In this way, the output for each dataset can be directly compared as the number of mapped reads per dataset and transcript size has already been taken into account.

Reads from parasitized and non-parasitized larvae were cleaned and combined, before de novo transcriptome assembly was carried out using Oases 0.1.18 [32]. The individual sets of reads were then mapped back to the transcripts using BWA 0.5.8a [76]. The average read depth (proportional to expression level) for each transcript was then calculated using SAMtools 0.1.8 [77]. The transcripts that had a greater than two-fold average read depth difference between the parasitized and non-parasitized sets were counted as being statistically biologically relevant and were selected for annotation. We used both CLC and Oases to compare assembly of contigs. In general, Oases produced similar contigs to CLC, although contig lengths produced by Oases were in some instances longer.

\section{BLAST homology search and annotation}

BLASTX algorithm [78] with an E-value cut off of $10^{-6}$ was applied to the National Centre for Biotechnology 
Table 4 D. semiclausum IV transcripts which were detected in parasitized $P$. xylostella larvae

\begin{tabular}{|c|c|c|c|c|c|c|c|}
\hline Protein & $\begin{array}{c}\text { Length } \\
\text { (nt) }\end{array}$ & $\begin{array}{l}\text { Accession } \\
\text { Number }\end{array}$ & Similarity (Protein/virus/Accession No.) & $\begin{array}{l}\text { length } \\
\text { (aa) }\end{array}$ & E value & $\begin{array}{l}\text { Nt. ID } \\
\%\end{array}$ & $\begin{array}{c}\text { Conserved } \\
\text { Domains }\end{array}$ \\
\hline Vankyrin 1 & $671^{*}$ & 257593 & vankyrin-b17 (HfIV) AAS90270.1 & 170 & $3.56 \mathrm{E}-52$ & 61 & Yes \\
\hline Vankyrin 2 & $519^{*}$ & ال257594 & vankyrin-d8.3 (HflV) BAF45734.1 & 159 & $6 \mathrm{E}-64$ & 80 & Yes \\
\hline Vankyrin 3 & 257 & 257595 & hypothetical protein 2 (HdIV) AAR99845.1 & 126 & $3.58 \mathrm{E}-23$ & 61 & Yes \\
\hline Vankyrin 4 & 361 & 257596 & vankyrin-b1(HfIV) AAX24120.1 & 167 & $2 \mathrm{E}-39$ & 76 & Yes \\
\hline Viral Innexin 1 & 1370 & J1257597 & viral innexin-b5.1 (HfIV) BAF45654.1 & 354 & $5 \mathrm{E}-95$ & 60 & Yes \\
\hline Viral Innexin 2 & 576 & 257598 & viral innexin-c16 (HfIV) AAS58041.1 & 371 & $2 \mathrm{E}-81$ & 75 & Yes \\
\hline Repeat element 1 & 833 & ال257599 & repeat element protein 7 (HdIV) AAR89179.1 & 224 & $4.32 \mathrm{E}-73$ & 67 & Yes \\
\hline Repeat element 2 & 697 & $J \mid 257600$ & $\begin{array}{l}\text { repeat element protein-d10.1 (HflV) } \\
\text { BAF45740.1 }\end{array}$ & 244 & $1.53 \mathrm{E}-72$ & 64 & Yes \\
\hline Repeat element 3 & 947 & 257601 & $\begin{array}{l}\text { repeat element protein-c18.1 (HfIV) } \\
\text { BAF45697.1 }\end{array}$ & 244 & 9.52E-94 & 71 & Yes \\
\hline Repeat element 4 & $859^{*}$ & J257602 & $\begin{array}{l}\text { repeat element protein-e2.3 (HflV) } \\
\text { BAF45758.1 }\end{array}$ & 209 & $3.40 \mathrm{E}-76$ & 67 & Yes \\
\hline Repeat element 5 & 656 & 257603 & repeat element protein (HdIV) AAO16959.1 & 225 & $1.21 \mathrm{E}-73$ & 59 & Yes \\
\hline Repeat element 6 & 500 & $J \mid 257604$ & $\begin{array}{l}\text { repeat element protein-d11.2 (HfIV) } \\
\text { BAF45744.1 }\end{array}$ & 244 & $1 \mathrm{E}-68$ & 72 & Yes \\
\hline Cysteine rich motif & 630 & J1257605 & cysteine motif gene-d9.1(HfIV) BAF45736.1 & 311 & $2.99 \mathrm{E}-55$ & 64 & Yes \\
\hline $\begin{array}{l}\text { Polar residue rich } \\
\text { protein }\end{array}$ & 671 & J1257606 & $\begin{array}{l}\text { polar residue rich protein-b13.2 (HfIV) } \\
\text { BAF45664.1 }\end{array}$ & 159 & $1.24 \mathrm{E}-12$ & 42 & No \\
\hline Unknown Protein & 256 & 257607 & C7-2.1 (TrIV) BAF45599.1 & 119 & $2.90 \mathrm{E}-17$ & 68 & Yes \\
\hline Unknown Protein & $2143^{*}$ & 257608 & c12.1 (HfIV) AAS68099.1 & 432 & $2 \mathrm{E}-107$ & 50 & No \\
\hline Unknown Protein & 418 & 257609 & P12 (HdIV) AAS83461.1 & 106 & $6 \mathrm{E}-18$ & 58 & No \\
\hline Unknown Protein & 584 & 257610 & c10.1 (HfIV) AAS90272.1 & 385 & $9.15 E-50$ & 51 & No \\
\hline Unknown Protein & 208 & J1257611 & b5.3 (HfIV) BAF45655.1 & 115 & 9.57E-13 & 69 & No \\
\hline
\end{tabular}

* Full length

Hf: Hyposoter fugitives

Hd: Hyposoter didymator

Tr: Tranosema rostrale

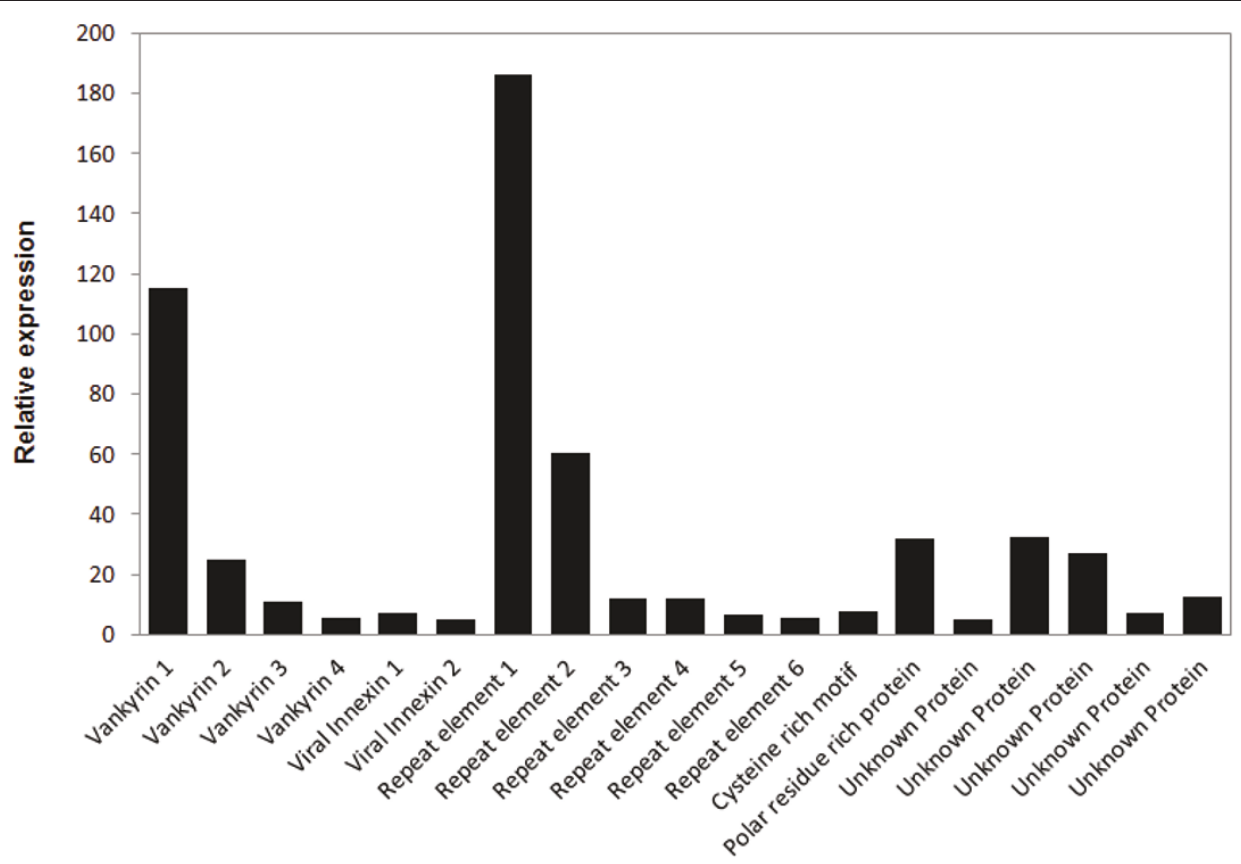

Figure 8 Relative gene expression values based on average read depth for all detected $D$. semiclausum ichnovirus genes. RPKM normalized values were used to generate the data. 


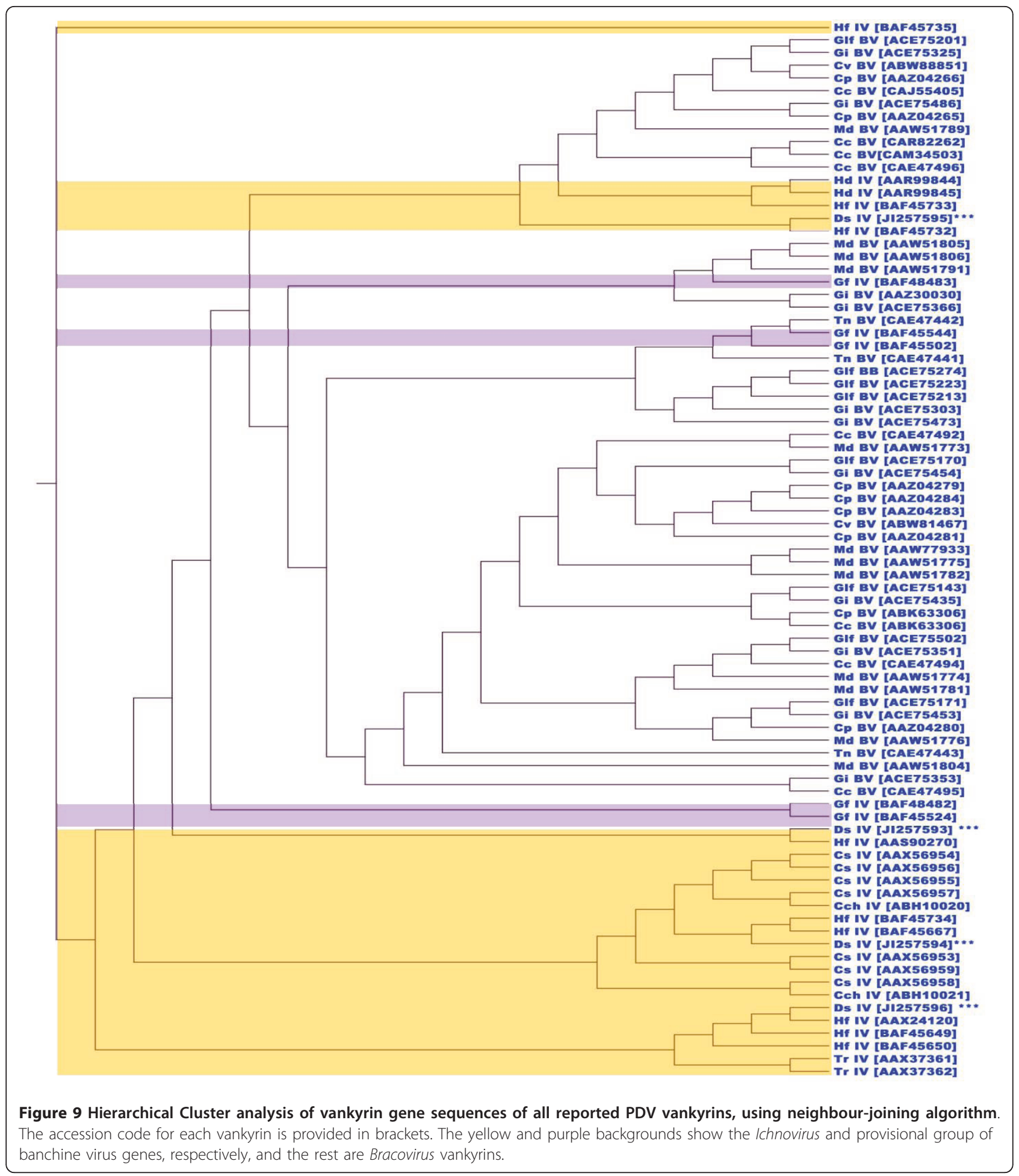

Information (NCBI) non-redundant protein sequence database, to determine the homology of sequences with known genes. In the absence of $P$. xylostella and $D$. semiclausum genome sequences, we discarded annotations that showed similarity to hymenopteran genes and tried to use annotations that showed the highest similarity to lepidopteran genes. Gene ontology and annotation were performed on all assembled contigs greater than 200 bp length by BLAST2GO software http://www.blast2go.org[79]. For gene ontology mapping, Blast2GO 
(which performs four different mapping strategies) was used, and the program defaults were applied for all annotation steps [79]. BLAST2GO allows the selection of a significance level for the False Discovery Rate (FDR), which was used as a cut-off at the $0.05 \%$ probability level. The data from InterPro terms [80], enzyme classification codes (EC), and metabolic pathways (KEGG, Kyoto Encyclopedia of Genes and Genomes) were merged with GO terms for a wide functional range cover in annotation.

For some of the identified D. semiclausum ichnovirus (DsIV) genes, ORFs were predicted and identified by using ORF finder at NCBI http://www.ncbi.nlm.nih.gov/ gorf/gorf.html. Predicted ORFs with highest BLASTp Evalues in internal comparisons involving other IV genes, were accepted for further analyses.

\section{Quantitative RT-PCR (qRT-PCR) validation of deep sequencing data}

Quantitative RT-PCR technique was used on the same RNA samples which were used for transcriptome profiling to verify deep sequencing results using three replicates, each obtained from a pool of 10 larvae. In addition, to observe gene expression levels at different time points after parasitization for a selected group of genes, another experiment was performed by parasitizing $2^{\text {nd }}$ instar $P$. xylostella larvae. For each time point after parasitization, a pool of 10 larvae was used. The RNA samples were extracted from larvae at 16, 24 and $48 \mathrm{hrs}$ after parasitization.

First strand cDNA was synthesized from $1 \mu \mathrm{g}$ of RNA using M-MuLV reverse transcriptase (New England BioLabs). The qPCR reaction consisted of $2 \mu \mathrm{L}$ of diluted cDNA (10 ng), $5 \mu \mathrm{L}$ of Platinum SYBR Green SuperMix-UDG with ROX (Invitrogen), and $1 \mu \mathrm{M}$ of each primer (Table 5) in $10 \mu \mathrm{L}$ total volume. Reactions were performed in triplicates in a Rotor-Gene thermal cycler (QIAGEN) under the following conditions: $50^{\circ} \mathrm{C}$ for 2

\section{Table 5 Primers used for qRT-PCR analyses to validate} deep sequencing data

\begin{tabular}{lll}
\hline Gene & Forward primer & Reverse Primer \\
\hline $\begin{array}{l}\text { Storage protein } \\
1\end{array}$ & CAAGACACGCTACGACGC & GTCGGCATGACGAAGTAC \\
Insulin receptor & GTACCCCTCGATCTCGCG & CCCACGTCAAGGGAACCC \\
JH epoxide & AGGATCTACGCGGAGGGC & TGGTACACCACTTCGTAC \\
hydrolase & & \\
Ecdysteroid & AACCCGAAGAGCCGAAGC & CTCTGTAGTCGCTGCTAC \\
regulated protein & & \\
Cuticle protein & CAGGATGACGAGTCTGGC & GTCTGCCTCGTATTCTAC \\
Toll receptor & CCTCCGGCAACGCCCTAG & CGCACAGAAATCAGAGG \\
Hemolin & AGCTCCAGAGACTACGCC & GTGTTGTAGGACCATTG \\
Gloverin & AGCTAGCCCGGCATCCGC & GACGGTAGCCCGCCTTAC \\
pxSerpin 3 & GAATAGCTTCTACTACGC & TGATAGCGAATCGGTAC \\
Actin & ATGGAGAAGATCTGGCAC & GGAGCCTCCGTGAGCAGC \\
\hline
\end{tabular}

min; $95^{\circ} \mathrm{C}$ for $2 \mathrm{~min}$; and 40 cycles of $95^{\circ} \mathrm{C}$ for $10 \mathrm{~s}, 60^{\circ}$ $\mathrm{C}$ for $15 \mathrm{~s}$, and $72^{\circ} \mathrm{C}$ for $20 \mathrm{~s}$, followed by melting curve generation $\left(68^{\circ} \mathrm{C}\right.$ to $\left.95^{\circ} \mathrm{C}\right)$. Melting curves for each sample were analyzed to check the specificity of amplification. Gene copy numbers were calculated using the Rotor-Gene software, and an endogenous actin reference gene was used for normalization.

\section{Acknowledgements}

This work was supported by a UQ Research Higher Degree scholarship to Etebari, an ARC Discovery grant (DP110102112) to Asgari and a Horticulture Australia Ltd grant (VG08048) to Glatz and Asgari.

\section{Author details}

${ }^{1}$ School of Biological Sciences, The University of Queensland, St Lucia QLD 4072 Australia. ${ }^{2}$ Australian Institute for Bioengineering and Nanotechnology, The University of Queensland, St Lucia QLD 4072 Australia. ${ }^{3}$ Agriscience Queensland, Department of Employment Economic Development and Innovation, Ecosciences Precinct, GPO Box 46, Brisbane 4001, Australia. ${ }^{4}$ South Australian Research and Development Institute (SARDI), Entomology, Waite Road, Urrbrae, South Australia, 5064, Australia.

\section{Authors' contributions}

KE performed experiments, analysed data and wrote the manuscript. RP, DS, $L N$ analysed data and contributed in writing the manuscript. RVG reviewed the manuscript and provided insect resources. SA conceived the study, analysed data and wrote the manuscript. All authors read and approved the final manuscript.

Received: 9 March 2011 Accepted: 9 September 2011 Published: 9 September 2011

\section{References}

1. Asgari S: Venom proteins from polydnavirus-producing endoparasitoids: Their role in host-parasite interactions. Arch Insect Biochem Physiol 2006, 61(3):146-156.

2. Bae S, Kim Y: Host physiological changes due to parasitism of a braconid wasp, Cotesia plutellae, on diamondback moth, Plutella xylostella. Comp Biochem Physiol a-Mol Integ Physiol 2004, 138(1):39-44.

3. Bai SF, Cai DZ, Li X, Chen XX: Parasitic castration of Plutella xylostella larvae induced by polydnaviruses and venom of Cotesia vestalis and Diadegma semiclausum. Arch Insect Biochem Physiol 2009, 70(1):30-43.

4. Gundersen-Rindal DE, Pedroni MJ: Larval stage Lymantria dispar microRNAs differentially expressed in response to parasitization by Glyptapanteles flavicoxis parasitoid. Arch Virol 2010, 155(5):783-787.

5. Kaeslin M, Reinhard M, Buhler D, Roth T, Pfister-Wilhelm R, Lanzrein B: Venom of the egg-larval parasitoid Chelonus inanitus is a complex mixture and has multiple biological effects. J Insect Physiol 2010, 56(7):686-694.

6. Shi M, Huang F, Chen YF, Meng XF, Chen XX: Characterization of midgut trypsinogen-like cDNA and enzymatic activity in Plutella xylostella parasitized by Cotesia vestalis or Diadegma semiclausum. Arch Insect Biochem Physiol 2009, 70(1):3-17.

7. Song KH, Jung MK, Eum JH, Hwang IC, Han SS: Proteomic analysis of parasitized Plutella xylostella larvae plasma. J Insect Physiol 2008, 54(8):1271-1280.

8. Zhu JY, Ye GY, Dong SZ, Fang Q, Hu C: Venom of Pteromalus puparum (Hymenoptera: Pteromalidae) induced endocrine changes in the hemolymph of its host, Pieris rapae. Arch Insect Biochem Physiol 2009, 71(1):45-53.

9. Huang F, Shi M, Chen YF, Cao TT, Chen XX: Oogenesis of Diadegma semiclausum (Hymenoptera:Ichneumonidae) and its associated polydnavirus. Microsc Res Tech 2008, 71(9):676-683.

10. Roossinck MJ: The good viruses: viral mutualistic symbioses. Nat Rev Microbiol 2011, 9(2):99-108.

11. Luckhart S, Webb BA: Interaction of a wasp ovarian protein and polydnavirus in host immune suppression. Dev Comp Immunol 1996, 20(1):1-21. 
12. Barandoc KP, Kim J, Kim Y: Cotesia plutellae bracovirus suppresses expression of an antimicrobial peptide, Cecropin, in the Diamondback Moth, Plutella xylostella, challenged by bacteria. J Microbio/ 2010, 48(1):117-123.

13. Fath-Goodin A, Kroemer JA, Webb BA: The Campoletis sonorensis ichnovirus vankyrin protein P-vank-1 inhibits apoptosis in insect Sf9 cells. Insect Mol Biol 2009, 18(4):497-506.

14. Kwon B, Song S, Choi JY, Je YH, Kim Y: Transient expression of specific Cotesia plutellae bracoviral segments induces prolonged larval development of the diamondback moth, Plutella xylostella. J Insect Physiol 2010, 56(6):650-658.

15. Tian SP, Zhang JH, Wang CZ: Cloning and characterization of two Campoletis chlorideae ichnovirus vankyrin genes expressed in parasitized host Helicoverpa armigera. J Insect Physiol 2007, 53(7):699-707.

16. Beckage NE: Parasitoids and polydnaviruses - An unusual mode of symbiosis in which a DNA virus causes host insect immunosuppression and allows the parasitoid to develop. Bioscience 1998, 48(4):305-311.

17. Volkoff AN, Jouan V, Urbach S, Samain S, Bergoin M, Wincker P, Demettre E, Cousserans F, Provost B, Coulibaly F, Legeai F, Beliveau C, Cusson M, Gyapay G, Drezen JM: Analysis of virion structural components reveals vestiges of the ancestral Ichnovirus genome. PLoS Pathog 2010, 6(5) e1000923.

18. Bigot Y, Samain S, Auge-Gouillou C, Federici BA: Molecular evidence for the evolution of ichnoviruses from ascoviruses by symbiogenesis. BMC Evo Biol 2008, 8:253.

19. Webb B, Fisher T, Nusawardani T: The Natural Genetic Engineering of Polydnaviruses. In Natural Genetic Engineering and Natural Genome Editing Edited by: Witzany G 2009, 1178:146-156.

20. Webb BA: Polydnavirus biology, genome structure, and evolution. In The insect viruses. Edited by: Miller LK, Ball LA. New York: Plenum Press; 1998:105-139.

21. Webb BA, Strand MR, Dickey SE, Beck MH, Hilgarth RS, Barney WE, Kadash K, Kroemer JA, Lindstrom KG, Rattanadechakul W, Shelby KS, Thoetkiattikul H, Turnbull MW, Witherell RA: Polydnavirus genomes reflect their dual roles as mutualists and pathogens. Virology 2006, 347(1):160-174.

22. David JP, Coissac E, Melodelima C, Poupardin R, Riaz MA, Chandor-Proust A Reynaud S: Transcriptome response to pollutants and insecticides in the dengue vector Aedes aegypti using next-generation sequencing technology. BMC Genomics 2010, 11:216.

23. Hegedus Z, Zakrzewska A, Agoston VC, Ordas A, Racz P, Mink M, Spaink HP, Meijer $\mathrm{AH}$ : Deep sequencing of the zebrafish transcriptome response to mycobacterium infection. Mol Immunol 2009, 46(15):2918-2930.

24. Morozova O, Marra MA: Applications of next-generation sequencing technologies in functional genomics. Genomics 2008, 92(5):255-264.

25. Xiang $L$, He D, Dong W, Zhang $Y$, Shao J: Deep sequencing-based transcriptome profiling analysis of bacteria-challenged Lateolabrax japonicus reveals insight into the immune-relevant genes in marine fish. BMC Genomics 2010, 11:472.

26. Xiao SQ, Jia JY, Mo DL, Wang QW, Qin LM, He ZY, Zhao XA, Huang YK, Li AN, Yu JW, Niu YN, Liu XH, Chen YS: Understanding PRRSV infection in porcine lung based on genome-wide transcriptome response identified by deep sequencing. PLoS One 2010, 5(6):e11377.

27. Scheibye-Alsing $K$, Hoffmann S, Frankel A, Jensen P, Stadler PF, Mang $Y$, Tommerup N, Gilchrist MJ, Nygard AB, Cirera S, Jorgensen CB, Fredholm M, Gorodkin J: Sequence assembly. Comput Biol Chem 2009, 33(2):121-136.

28. Chen M, Zhao J-Z, Collins HL, Earle ED, Cao J, Shelton AM: A critical assessment of the effects of Bt transgenic plants on parasitoids. PLoS One 2008, 3(5):e2284

29. Takeda T, Nakamatsu Y, Tanaka T: Parasitization by Cotesia plutellae enhances detoxifying enzyme activity in Plutella xylostella. Pestic Biochem Physiol 2006, 86(1):15-22

30. Mu YN, Ding F, Cui P, Ao JQ, Hu SN, Chen XH: Transcriptome and expression profiling analysis revealed changes of multiple signaling pathways involved in immunity in the large yellow croaker during Aeromonas hydrophila infection. BMC Genomics 2010, 11:506.

31. Brent MR: Steady progress and recent breakthroughs in the accuracy of automated genome annotation. Nat Rev Gen 2008, 9(1):62-73.

32. Oases: a transcriptome assembler for very short reads. [http://www.ebi. ac.uk/ zerbino/oases].
33. Shelby KS, Cui L, Webb BA: Polydnavirus-mediated inhibition of lysozyme gene expression and the antibacterial response. Insect Mol Biol 1998, 7(3):265-272.

34. Barandoc KP, Kim Y: Translation inhibitory factors encoded in Cotesia plutellae bracovirus require the 5 '-UTR of a host mRNA target. Comp Biochem Physiol B-Biochem Mol Biol 2010, 156(2):129-136.

35. Nicolas E, Nappi AJ, Lemaitre B: Expression of antimicrobial peptide genes after infection by parasitoid wasps in Drosophila. Dev Comp Immunol 20(3):175-181.

36. Provost B, Jouan V, Hilliou F, Delobel P, Bernardo P, Ravallec M, Cousserans F, Wajnberg E, Darboux I, Fournier P, Strand MR, Volkof AN: Lepidopteran transcriptome analysis following infection by phylogenetically unrelated polydnaviruses highlights differential and common responses. Insect Biochem Mol Biolo 2011, 41(8):582-591.

37. Eum JH, Seo YR, Yoe SM, Kang SW, Han SS: Analysis of the immuneinducible genes of Plutella xylostella using expressed sequence tags and cDNA microarray. Dev Comp Immunol 2007, 31(11):1107-1120.

38. Abdel-Latief $M$, Hilker $M$ : Innate immunity: Eggs of Manduca sexta are able to respond to parasitism by Trichogramma evanescens. Insect Biochem Mol Biol 2008, 38(2):136-145.

39. Kim J, Kim Y: Transient expression of a viral histone H4, CpBV-H4, suppresses immune-associated genes of Plutella xylostella and Spodoptera exigua. J Asia-Pacific Entomol 2010, 13(4):313-318.

40. Beck M, Theopold U, Schmidt O: Evidence for serine protease inhibitor activity in the ovarian calyx fluid of the endoparasitoid Venturia canescens. J Insect Physiol 2000, 46(9):1275-1283.

41. Rai S, Aggarwal KK, Mitra B, Das TK, Babu CR: Purification, characterization and immunolocalization of a novel protease inhibitor from hemolymph of tasar silkworm, Antheraea mylitta. Peptides 2010, 31(3):474-481.

42. Aguilar R, Jedlicka AE, Mintz M, Mahairaki V, Scott AL, Dimopoulos G: Global gene expression analysis of Anopheles gambiae responses to microbial challenge. Insect Biochem Mol Biol 2005, 35(7):709-719.

43. Asgari S, Zareie R, Zhang GM, Schmidt O: Isolation and characterization of a novel venom protein from an endoparasitoid, Cotesia rubecula (Hym: Braconidae). Arch Insect Biochem Physiol 2003, 53(2):92-100.

44. Schlenke TA, Morales J, Govind S, Clark AG: Contrasting infection strategies in generalist and specialist wasp parasitoids of Drosophila melanogaster. PLoS Pathog 2007, 3:1486-1501.

45. Barat-Houari M, Hilliou F, Jousset FX, Sofer L, Deleury E, Rocher J, Ravallec M, Galibert L, Delobel P, Feyereisen R, Fournier P, Volkoff AN: Gene expression profiling of Spodoptera frugiperda hemocytes and fat body using CDNA microarray reveals polydnavirus-associated variations in lepidopteran host genes transcript levels. BMC Genomics 2006, 7(160):1-20.

46. Wertheim B, Kraaijeveld AR, Schuster E, Blanc E, Hopkins M, Pletcher SD, Strand MR, Partridge L, Godfray HCJ: Genome-wide gene expression in response to parasitoid attack in Drosophila. Genome Biol 2005, 6(11):R94.

47. Govind S: Innate immunity in Drosophila: Pathogens and pathways. Insect Science 2008, 15(1):29-43.

48. Antonova Y, Alvarez KS, Kim YJ, Kokoza V, Raikhel AS: The role of NF-kappa $\mathrm{B}$ factor REL2 in the Aedes aegypti immune response. Insect Biochem Mol Biol 2009, 39(4):303-314.

49. Shrestha S, Kim HH, Kim Y: An inhibitor of NF-kB encoded in Cotesia plutella bracovirus inhibits expression of antimicrobial peptides and enhances pathogenicity of Bacillus thuringiensis. J Asia-Pacific Entomol 2009, 12(4):277-283.

50. Thoetkiattikul H, Beck MH, Strand MR: Inhibitor kappa B-like proteins from a polydnavirus inhibit NF-kappa B activation and suppress the insect immune response. Proc Natl Acad Sci USA 2005, 102(32):11426-11431.

51. Asgari S: Endoparasitoid venom proteins as modulators of host immunity and development. In Recent advances in the biochemistry, toxicity and mode of action of parasitic wasp venom. Edited by: Rivers D, Yoder J. Kerala: Research Signpost; 2007:57-73.

52. Pennacchio F, Strand MR: Evolution of developmental strategies in parasitic hymenoptera. Annu Rev Entomol 2006, 51:233-258.

53. Li X, Cui L, Bai S, Yuan G: The capacity of regulation on development and host diamondback moth, Plutella xylostella, by endoparasitoids. J Henan Agric Univ 2005, 39:308-311.

54. Dover BA, Davies DH, Strand MR, Gray RS, Keeley LL, Vinson SB: Ecdysteroid-titre reduction and developmental arrest of last-instar 
Heliothis virescens larvae by calyx fluid from the parasitoid Campoletis sonorensis. J Insect Physiol 1987, 33(5):333-338.

55. Soller M, Lanzrein B: Polydnavirus and venom of the egg-larval parasitoid Chelonus inanitus (Braconidae) induce developmental arrest in the prepupa of its host Spodoptera littoralis (Noctuidae). J Insect Physiol 1996, 42(5):471-481.

56. Webb BA, Dahlman DL: Developmental pathology of Heliothis virescns larvae parasitized by Microplitis croceipes parasite mediated host developmental arrest. Arch Insect Biochem Physiol 1985, 2(2):131-143.

57. Lee S, Kim Y: Juvenile hormone esterase of diamondback moth, Plutella xylostella, and parasitism of Cotesia plutellae. J Asia-Pacific Entomol 2004, 7(3):283-287.

58. Li S, Falabella P, Kuriachan I, Vinson SB, Borst DW, Malva C, Pennacchio F: Juvenile hormone synthesis, metabolism, and resulting haemolymph titre in Heliothis virescens larvae parasitized by Toxoneuron nigriceps. $J$ Insect Physiol 2003, 49(11):1021-1030.

59. Pfister-Wilhelm R, Lanzrein B: Stage dependent influences of polydnaviruses and the parasitoid larva on host ecdysteroids. J Insect Physiol 2009, 55(8):707-715.

60. Schafellner C, Marktl RC, Schopf A: Inhibition of juvenile hormone esterase activity in Lymantria dispar (Lepidoptera, Lymantriidae) larvae parasitized by Glyptapanteles liparidis (Hymenoptera, Braconidae). I Insect Physiol 2007, 53(8):858-868.

61. Zhu JY, Ye GY, Dong SZ, Fang Q, Hu C: Venom of Pteromalus puparum (Hymenoptera: Pteromalidae) induced endocrine changes in the hemolymph of its host, Pieris rapae (Lepidoptera:Pieridae). Arch Insect Biochem Physiol 2009, 71(1):45-53.

62. Meszaros M, Morton DB: Isolation and prtial caracterization of a gene from trachea of Manduca sexta that requires and is negatively regulated by ecdysteroids. Deve Biol 1994, 162(2):618-630.

63. Dahlman DL, Coar DL, Koller CN, Neary TJ: Contributing factors to reduced ecdysteroid titers in Heliothis virescens parasitized by Microplitis croceipes. Arch Insect Biochem Physiol 1990, 13(1-2):29-39.

64. Gelman DB, Reed DA, Beckage NE: Manipulation of fifth-instar host (Manduca sexta) ecdysteroid levels by the parasitoid wasp Cotesia congregata. J Insect Physiol 1998, 44(9):833-843.

65. Pruijssers AJ, Falabella P, Eum JH, Pennacchio F, Brown MR, Strand MR: Infection by a symbiotic polydnavirus induces wasting and inhibits metamorphosis of the moth Pseudoplusia includens. J Exp Biol 2009, 212(18):2998-3006.

66. Strand MR, Dover BA, Johnson JA: Alterations in the ecdysteroid and juvenile hormone esterase profiles of Trichoplusia ni parasitized by the polyembryonic wasp Copidosoma floridanum. Arch Insect Biochem Physiol 1990, 13(1-2):41-51.

67. Touhara K, Prestwich GD: Juvenile hormone epoxide hydrolase, photoaffinity labeling, purification and characterization from tobacco hornworm eggs. J Biol Chem 1993, 268(26):19604-19609.

68. Dover BA, Menon A, Brown RC, Strand MR: Suppression of juvenile hormone estrase in Heliothis virescens by Microplitis demolitor calyx fluid. J Insect Physiol 1995, 41(9):809-817.

69. Nalini M, Kim Y: A putative protein translation inhibitory factor encoded by Cotesia plutellae bracovirus suppresses host hemocyte-spreading behavior. J Insect Physiol 2007, 53(12):1283-1292.

70. Shelby KS, Webb BA: Polydnavirus infection inhibits synthesis of an insect plasma protein arylphorin. J Gen Virol 1994, 75:2285-2292.

71. Shelby KS, Webb BA: Polydnavirus infection inhibits translation of specific growth-associated host proteins. Insect Biochem Mol Biol 1997, 27(3):263-270.

72. Tanaka K, Lapointe R, Barney WE, Makkay AM, Stoltz D, Cusson M, Webb BA: Shared and species-specific features among ichnovirus genomes. Virology 2007, 363(1):26-35.

73. Strand MR: Polydnaviruses. In Insect Virology. Edited by: Asgari S, Janson K. Norfolk: Caister Academic Press; 2010:171-197.

74. Lapointe R, Tanaka K, Barney WE, Whitfield JB, Banks JC, Beliveau C, Stoltz D, Webb BA, Cusson M: Genomic and morphological features of a banchine polydnavirus: Comparison with bracoviruses and ichnoviruses. J Virol 2007, 81(12):6491-6501.

75. CLC Bio: CLC genomics workbench. [http://www.clcbio.com].

76. Li H, Durbin R: Fast and accurate short read alignment with BurrowsWheeler transform. Bioinformatics 2009, 25(14):1754-1760.
77. Li H, Handsaker B, Wysoker A, Fennell T, Ruan J, Homer N, Marth G, Abecasis G, Durbin R, Genome Project Data P: The Sequence alignment/ map format and SAMtools. Bioinformatics 2009, 25(16):2078-2079.

78. Altschul SF, Madden TL, Schaffer AA, Zhang JH, Zhang Z, Miller W, Lipman DJ: Gapped BLAST and PSI-BLAST: a new generation of protein database search programs. Nuc Acids Res 1997, 25(17):3389-3402.

79. Conesa A, Gotz S: Blast2GO: A comprehensive suite for functional analysis in plant genomics. Int J Plant Genomics 2008, 2008:619832.

80. Hunter S, Apweiler R, Attwood TK, Bairoch A, Bateman A, Binns D, Bork P, Das U, Daugherty L, Duquenne L, Finn RD, Gough J, Haft D, Hulo N, Kahn D, Kelly E, Laugraud A, Letunic I, Lonsdale D, Lopez R, Madera M, Maslen J, McAnulla C, McDowall J, Mistry J, Mitchell A, Mulder N, Natale D, Orengo C, Quinn AF, Selengut JD, Sigrist CJA, Thimma M, Thomas PD, Valentin $F$, Wilson $D, W u C H$, Yeats C: InterPro: the integrative protein signature database. Nuc Acids Res 2009, 37:D211-D215.

doi:10.1186/1471-2164-12-446

Cite this article as: Etebari et al:: Deep sequencing-based transcriptome analysis of Plutella xylostella larvae parasitized by Diadegma semiclausum. BMC Genomics 2011 12:446.

\section{Submit your next manuscript to BioMed Central and take full advantage of:}

- Convenient online submission

- Thorough peer review

- No space constraints or color figure charges

- Immediate publication on acceptance

- Inclusion in PubMed, CAS, Scopus and Google Scholar

- Research which is freely available for redistribution

Submit your manuscript at www.biomedcentral.com/submit
C Biomed Central 